\title{
Decision makings in key remanufacturing activities to optimise remanufacturing outcomes: a review
}

\begin{abstract}
The importance of remanufacturing has been increasing since stricter regulations on protecting the environment were enforced. Remanufacturing is considered as the main means of retaining value from used products and components in order to drive a circular economy. However, it is more complex than traditional manufacturing due to the uncertainties associated with the quality, quantities and return timing of used products and components. Over the past few years, various methods of optimising remanufacturing outcomes have been developed to make decisions such as identifying the best End-OfLife (EOL) options, acquiring the right amounts of cores, deciding the most suitable disassembly level, applying suitable cleaning techniques, and considering product commonality across different product families. A decision being made at one remanufacturing activity will greatly affect the decisions at subsequent activities, which will affect remanufacturing outcomes, i.e. productivity, economic performance effectiveness, and the proportion of core that can be salvaged. Therefore, a holistic way of integrating different decisions over multiple remanufacturing activities is needed to improve remanufacturing outcomes, which is a major knowledge gap. This paper reviews current remanufacturing practice in order to highlight both the challenges and opportunities, and more importantly, offers useful insights on how such a knowledge gap can be bridged.
\end{abstract}

\section{Keywords}

Remanufacturing, core acquisition, EOL option, disassembly level, cleaning, MRP

\section{Background}

Remanufacturing is one of the well-known recovery methods which can restore a used product (a core) to its original manufacturer's specification from a quality, performance and warranty perspective. Remanufacturing can also help manufacturers reduce waste and avoid landfill. Also, the manufacturers can save manufacturing costs, disposal costs and energy usage. Although remanufacturing and conventional manufacturing can both use batch or flow production and similar machine tools, remanufacturing is much more complex (Ian et al., 2015). The causes of the complexity in remanufacturing are: (i) Uncertainty in timing and quantities of returned cores; (ii)Balancing returned cores with demand; (iii) The disassembly of cores; (iv)The uncertain recovery rate of cores; (v).The need for reverse logistics; (vi)Difficulty of material matching; (vii)Uncertainty of material's routeings; and (viii)Uncertainty of processing times(Guide, 2000, Ian et al., 2015, Morgan and Gagnon, 2013) 
Remanufacturing consists of seven key activities to turn cores into remanufactured products/components including core acquisition, disassembly, cleaning, inspection, reworking, reassembly, and testing(Ijomah, 2002). Decision making about each remanufacturing activity will affect decision making in succeeding remanufacturing activities. However, no academic research has reviewed the literature about decision makings in key remanufacturing activities to optimise remanufacturing outcomes. Decision making becomes even more complex when considering the decision factors associated with each single activity and the correlation between the decision factors across multiple activities simultaneously. This implies that the practice of considering decision factors across multiple remanufacturing activities has not yet been explored. Therefore, the purpose of this review paper is to generate useful insights into how remanufacturing outcomes can be optimised involving multiple decision factors across multiple remanufacturing activities. Inspection and testing were not examined in this study since remanufacturers have no alternative but to follow OEMs specifications to operate full processes of inspection and testing to guarantee the quality of remanufactured products. Hence, the scope of this review only covered five activities of remanufacturing as shown in Figure 1. Figure 1 shows five major decisions across different activities of remanufacturing. It should be noted that some decisions can be made for a single activity while others can be made over two or more activities. Moreover, another important finding from our review is that there are significant correlations between decisions regarding disassembly level, core acquisition or purchasing new components/products and EOL options, hence to be referred to integrated decision making.

This paper is divided into four sections. Our review methodology is detailed in Section 2. Section 3 discusses important findings over major decisions over multiple remanufacturing activities. Section 4 concludes this paper with recommendations for future research.

[Figure 1. Streams of decision making regarding remanufacturing activities]

\section{Review methodology}

In order to obtain a better understanding of the key decisions made in remanufacturing, five automotive remanufacturing companies were visited and a literature review was carried out. These companies included one independent remanufacturer, three contract remanufacturers and one OER (original equipment remanufacturer) which are the three typical types of remanufacturers. To be specific, three companies were specialists in engines, one in transmissions and one in the diesel injection systems. The components produced by these five companies are the most commonly remanufactured components in the automotive sector. To conduct the literature review, the authors adopted the three stages recommended by Sánchez-Meca (2010) and Suárez et al (2017), which are: 1. formulation of the problem 2. criteria for inclusion and exclusion of articles and 3. the search and selection of articles. 


\subsection{Formulation of the problem}

The first procedure was to identify the questions which would provide the answers required by this study. These research questions are as follows:

1. What are the key decisions made in remanufacturing?

2. What are the under-studied factors for each major decision?

3. What future research methods should be applied for each major decision?

4. What knowledge gaps are there in the multiple decisions across multiple remanufacturing activities?

\subsection{Criteria of inclusion and exclusion of articles}

This procedure is to set the same search protocols for all the papers included in order to guarantee the consistency of the search results. The following criteria were used:

2.2.1 Temporal scope: This study was conducted during March 2018. The selected papers cover the period from 1996 to 2018.

2.2.2 Research quality: In order to cover all the relevant and qualified evidence, the selected articles were papers written in the first two quarters (Q1 and Q2) chosen by SJR (SCIMAGO journal ranking) or review articles cited by the articles from Q1 and Q2 or a dissertation which reviewed a relevant topic. SJR (SCIMAGO journal ranking) is an alternative method of checking the quality of papers because SJR shows a larger collection of journals and includes open access papers (Falagas et al., 2008). Also, SJR depends on the prestige of the cited journals over a period of three years (Suárez et al., 2017). It has been recommended to select the suitable papers from Q1 which includes the top 25\% cited journals (Bornmann and Marx, 2014, Bornmann and Williams, 2017). Therefore, the first two quarters (i.e. Q1 and Q2) of the highest ranking journal papers were chosen to include a greater number of eligible papers than those obtained by the previous method. The second type of articles included were review articles since analysing review articles can provide an overview of areas of interest (Featherstone, 2015). Although some review articles are excluded by the SJR, most of them are cited in the top 50\% cited journals as shown in Table 1. Also, additional relevant papers were found from the review articles. These additional relevant papers are in Q1 or Q2 which helped to guarantee the research quality. Moreover, the dissertation which reviewed the relevant topic were also included. Although dissertations are known as 'grey literature' and not cited in the Q1 and Q2 papers, their quality can be guaranteed because they are documents which require an external review by specialists who decide if they are at an appropriate level for the award of a degree (Lisa et al., 2017).

2.2.3 Area of knowledge: After reviewing the literature and visiting the five automotive remanufacturing companies, the authors found that the main decisions are based on the identification of the best End-Of-Life (EOL) options, acquiring the right amounts of cores, deciding on the most 
suitable disassembly level, applying suitable cleaning techniques and MRP (Material requirement planning) in remanufacturing.

2.2.4 Publication language: Papers not written in English were excluded.

\subsection{Article search and selection}

This procedure shows how this study selected articles to fulfil the criteria from section 2.2. The procedure is divided into two methods: traditional SLR (systematic literature review) and an additional method.

Firstly, traditional SLR was conducted in this study since this method is acceptable for a wide range of academic research areas. SLR includes or excludes criteria from its search terms and shows how to check the quality of sources (Morgan and Gagnon, 2013, Merli et al., 2018). Three well-known databases, Scopus, Web of Science and ScienceDirect, were used in order to cover multi-disciplinary areas. By using the SJR assessment, the first two quarters of the highest ranking journal papers were chosen by searching the keywords. The keywords used for making decisions are shown in Figure 2. Then, abstracts of all the papers selected from the SLR were read. Subsequently, a complete analysis was conducted of all relevant papers and duplicate papers were omitted.

After the traditional SLR, further steps were employed to identify any additional review articles since SLR may not include all the necessary evidence. Although some review articles are 'grey' sources such as conference papers and a dissertation, they can contribute significant knowledge to a systematic literature review (Paez, 2017, McAuley et al., 2000, Benzies et al., 2006). These 'grey' sources can provide essential data not found within commercially published articles. Therefore, to compensate for the limitation of searching for keywords, these additional steps were applied to core acquisition, material requirement planning and cleaning since comprehensive review articles had already been conducted on these topics by a number of articles as reported in Table 1.

In conclusion, the combination of SLR and the additional steps can help reveal new findings that are not reported in those review articles, hence increasing the comprehensiveness of our review findings. The final results of the paper selection are detailed in Figure 2.

[Table 1. List of review articles]

[Figure 2. Paper selection]

\section{Results and discussion}

In this section, five major decisions that affect remanufacturing outcomes are discussed. Since these decisions can be considered at one or more remanufacturing activities and each activity may involve 
one or more of these decisions, it is vital to examine the relationship between decisions and remanufacturing activities. Also, this section discusses the research gaps and suggests areas for future research.

\subsection{End Of life (EOL)options}

Since not all used products/components can be remanufactured, other EOL options are considered. According to Östlin (2008) and practices in remanufacturing, the selection of EOL options can be made for remanufacturing activities as shown in figure 3. EOL options can be determined before and after disassembly, after cleaning, during and after reworking and during reassembly While the common EOL options considered are reuse, remanufacture, recycling and disposal, other EOL options mentioned in the literature include reconditioning, replacement, dismantling/disassembly, repair, salvage, incineration, resale and cannibalision as seen in Table 2.

[Figure 3. Selection of EOL options for different remanufacturing activities]

[Table 2. Other EOL options discussed in the literature]

Table 3 reports a total of 33 papers which examine EOL options between 2001 and 2018. For ease of comparison, each paper is characterised by the types of products examined, the level of decisions developed, the methodologies applied to determine the best EOL options, and the types of decision factors considered in the EOL selection. Regarding the types of products, it was found that most research papers examined the selection of EOL options over electronic (42\%) or automotive products (33\%). Hence, research opportunities are noted for other under-researched industries such as industrial tooling and aerospace which usually use remanufactured products (CRR, 2010).

[Table 3. Decision makings in EOL options]

EOL options can be categorised into product-level and component-level. Han et al. (2013) pointed out that most previous studies examined only EOL options at product-level because selecting EOL options at component-level was much more complex. However, our review results indicate that 22 of 33 papers examined the selection of EOL options at component-level which became more popular after 2013. Our findings reinforce the fact that EOL options at component-level are more practical in real life (Han et al., 2013). In addition, observations made from our company visits show that remanufacturers tend to consider EOL options for each component of the product rather than for the whole product. For example, different EOL options are often considered for the crankshaft which is one of the engine components. Therefore, choosing EOL options at component-level is surely an important topic for further study. 
From 2001-2018, mixed integer programming (MIP) was the most frequently used method to select the best EOL option when considering two or more decision factors (13 of 33 papers). Genetic algorithms (GA) were the next most frequently used method ( 6 of 33 papers), followed by LCA ( 5 papers) and Pareto optimal (5 papers), fuzzy logic ( 3 papers), MINLP (3 papers) and AHP ( 2 papers). LCA was the most commonly used method to consider the environmental factors (e.g. Li et al. (2016b) and Karaulova and Bashkite(2016)). Table 4 shows that metaheuristics (GA, ICA and ACSA), MINLP and AHP, were never used before 2012. Since 2012, metaheuristics have become more common since these methods are deemed more efficient and effective when dealing with the selection of EOL options with two or more decision factors, which is also known as multi-criteria decision making (Ma et al., 2011, Jun et al., 2012, Yang et al., 2016c, Meng et al., 2016b). MINLP has received more attention since 2012 (Jun et al., 2012) as some economic factors such as recovery cost might be non-linearly associated with product quality (Jun et al., 2007) as shown in Figure 4. The subjective weighting method (ex. AHP, point allocation, ranking) is also beneficial for the selection of EOL options when the nature of remanufacturing is uncertain. The subjective weighting method can reduce inaccuracy between the assumptions and real practice because the weighting is determined by experts who gain knowledge from past experience. In short, it is believed that more researchers will employ GA, other metaheuristics, MINLP and subjective weighting methods to select the best EOL options.

[Table 4. Methods used in selecting EOL options]

[Figure 4. The relationship between recovery cost and quality (Jun et al., 2007)]

Figure 5 shows that $64 \%$ of all papers examined two or more decision factors (objectives) when selecting EOL options. This helps to reinforce the fact that selecting EOL options is often formulated as multiple criteria decision making (MCDM) problems. Having said that, three studies were found to study a single objective such as engineering (Murayama and Shu, 2001, Hu et al., 2014), or the environment ( $\mathrm{Li}$ et al., 2016b). 57\% of all papers considered economic factors (e.g. McKenna et al. (2013) and Steeneck and Sarin (2017)) or economic and environmental factors (e.g. Lee et al. (2001) and Ghazalli and Murata (2011)) while other factors have been under-studied. Since 2014, some objectives have been examined together which was never the case in studies between 2001 and 2013. For example, Ondemir and Gupta (2014a) and Karaulova and Bashkite (2016) focused on economic, engineering and environmental factors simultaneously, while Li et al. (2016b) emphasised the environmental objectives and Ziout et al. (2014) considered multiple objectives including the economic, environmental, engineering, social and legal factors at the same time. Our findings suggest that researchers have tended to consider more factors (objectives) in recent years (2014-2018) as seen in figure 6. This tendency will probably be the future direction as such a holistic approach is required to consider multiple factors for supporting sustainable production (Ziout et al., 2014). This view is also supported by Carpenter and Sanders (2009) who stated that PESTEL (political, economic, societal, 
technical, environmental and legal aspects) have been used successfully in operational frameworks for various types of organisations.

[Figure 5. Percentage of papers by objectives]

[Figure 6. Percentage of papers by objectives for each publication year]

\subsection{Core acquisition management}

Core acquisition is an activity to balance the demand and return of cores by considering the quantities, timing and quality of the cores (Wei et al., 2015). Core acquisition usually occurs in pre-disassembly but can be also considered during disassembly. This is because remanufacturers usually have more information about the conditions of cores after disassembling and they can then decide if new cores are needed. In the following sub-sections, the types of factors and optimisation methods used in core acquisition management are reviewed.

\subsubsection{Factors in core acquisition management}

\subsubsection{Acquisition price}

Acquisition price can be categorised into two types including linear and non-linear functions. The majority of research papers ( 8 of 12 papers) assumed that the acquisition price is a linear function as follows. Acquisition price $(\mathrm{A})=\mathrm{uN}$, where $\mathrm{u}$ is a constant unit acquisition cost and $\mathrm{N}$ refers to the number of acquired products/components (Galbreth and Blackburn, 2006, Yang et al., 2014, Bulmus et al., 2014, Teunter and Flapper, 2011, Seidi and Kimiagari, 2010). However, some researchers have suggested that acquisition can also be a non-linear function because the uncertain return rate of usedproduct returns and the fluctuating demand for remanufactured products will influence the acquisition price dynamically. In the non-linear case, Galbreth and Blackburn (2006) considered that acquisition price is an increasing convex function over time because of the scarcity of products. In addition, the acquisition price can fluctuate over time depending on the serviceable inventory level (Cai, 2014, Xie et al., 2015).

\subsubsection{Demand rate and return rate}

When core acquisition is being mathematically modelled, both the demand rate of remanufactured products and the return rate of cores are assumed to be in different forms: deterministic, stochastic or random. Deterministic forms are usually adopted as it helps simplify the models. However, in real practice, both demand rate and return rate are highly uncertain, especially for independent remanufacturers who have less control over both customer demand and customer return. Therefore, more complex models have been developed for stochastic and random forms. To improve model accuracy, stochastic models have been developed with both demand rate and return rate following 
certain probability distributions. Whereas both demand rate and return rate can be deemed as random functions which were inspired by a real industrial case (e.g. Zhou and Yu (2011)). Tables 5 shows all three forms used for both the demand and the return rate, each with examples from the literature. It should be noted that there are a limited number of research papers which assume random demand rate and random return rate.

[Table 5. The list of papers categorised by types of demand rate and types of return rate]

\subsubsection{Quality level}

The remanufacturers, such as ReCellular (Guide and Wassenhove, 2001) and Caterpillar (Wei et al., 2015), have classified cores into different quality levels (or grades) which help determine the remanufacturing costs. In cases of multiple grades of cores, the quality distribution of each grade can be divided into two types: discrete and continuous. Although discrete distribution is less realistic, it is more frequently used than continuous distribution which is more complex. If discrete distribution is applied, cores of the same grade have the same quality level and remanufacturing costs. The number of cores at each grade is assumed to be deterministic (Guide et al., 2003, Galbreth and Blackburn, 2006, Seidi and Kimiagari, 2010, Teunter and Flapper, 2011, Pokharel and Liang, 2012, Yang et al., 2014, Yang et al., 2016a). With regard to continuous distribution, Ferguson (2011) has proposed that the returned cores have quality $q \in[0,1]$ as shown in Figure 7 , where 0 is the minimum quality of returned cores, 1 is the maximum quality of returned cores and the quality probability density function changes over time (Wei et al., 2015) . Also, Robotis et al.(2012) have assumed that only a portion from 0 to 1 of the whole product is remanufacturable (Wei et al., 2015).

[Figure 7. The classification of returned cores adopted by Ferguson (2011)]

\subsubsection{The modelling approach in core acquisition management}

According to a review by Wei et al. (2015), the most widely recognised technique to optimise the return quantities is through adjusting acquisition effort. Some of the most commonly used modelling approaches are game theory (Bulmus et al., 2013), optimal control (Zhou and Yu, 2011), Markov chain (Vercraene et al., 2014) and mixed integer programming (Nenes and Nikolaidis, 2012). Our findings also uncover other modelling approaches such as non-linear programming (Seidi and Kimiagari, 2010), real option valuation (Wei and Tang, 2014), Bayesian estimation of distributed lag model (Clottey, 2012, Clottey, 2016) and multi-period stochastic dynamic programming (Xie et al., 2015). Table 6 illustrates that most papers about core acquisition (14 of 20) use optimal control as the modelling approach since optimal control is a mature mathematical discipline in science and engineering. 
Table 6 shows that researchers mostly consider demand, acquisition price, remanufacturing costs and return rates when optimising core acquisition. There has been limited research which has considered product lifecycles, activity-based costs, changeable prices, capacity constraints, safety stock, activitybased quantity, part levels, timing constraints, product commonality, remanufacturing yield, optimal remanufacturing level and environmental factors. Moreover, most studies assume that the demand and return rate are deterministic or stochastic while quality is deemed as uncertain but can only be specified by certain probability distributions. In real practice, remanufacturers face challenges due to uncertainties such as unpredictable customer demand for remanufactured products, unknown availability of the returned products/components and the unpredictable condition of returned products/components. Therefore, there are opportunities for future research to focus on random demand rate, return rate and quality of cores, which is more realistic. Also, under-researched factors should be included in the decision making process. For example, quality may be considered as a function of operational time or the useful life of a product since the condition of products/components usually varies over time. In addition, quality can be also considered as a function of recovery cost which is less subjective as recovery effort is a good reflection of the quality of returned products/components. If the cores are of better quality, less effort will be needed to recover the cores into a like-new condition.

[Table 6. Review findings about factors and modelling approach used in core acquisition]

\subsection{Material requirement planning (MRP)}

In remanufacturing, MRP considers the unpredictable reusability of components from cores and uncertain processing times of each activity during remanufacturing (Depuy et al., 2007). Therefore, MRP in remanufacturing is more complex than that of traditional manufacturing.

Our review found that there are 19 papers about MRP in remanufacturing. Only 4 out of 19 papers (21\%) were found to be relevant to the management of component commonality in remanufacturing. The component commonality among multiple products is an important area because it imposes additional challenges on the scheduling of remanufacturing activities (Kim et al., 2007, Gupta and Taleb, 1994, Krupp, 1993). Although Reverse MRP (RMRP) can forecast the demand for all components of products, stand-alone RMRP cannot meet other economic objectives, such as monetarybased objectives. Please see the details of RMRP in Taleb et al. (1997). However, linear and integer programming models can accomplish cost-based objectives by finding the optimal solution for problems with capacity constraints (Morgan and Gagnon, 2013). Regarding component planning and scheduling, 7 papers were reviewed by Morgan and Gagnon (2013) covering research papers from 1991-2011 which are included in our analysis. Moreover, we include two additional papers: one is Ullerich (2014) which reviews papers from 1955-2012 and another is Ji et al. (2015) which is the latest paper to examine component planning and scheduling. Finally, a total of 13 papers (4 papers using SLR 
and 9 papers using additional methods) are reviewed regarding component planning and scheduling in consideration of component commonality across multiple products as shown in Table 7.

Table 7 also reveals additional new findings to those of previous studies. First, the minority of research papers ( 3 of 13) assumed incomplete disassembly over multiple periods. The majority of articles ( 9 of 13) did not include remanufacturing in their decision making. Also, limited papers were found considering capacity constraints, adaptive sequences and fluctuating lead times when performing MRP. Core conditions were included in mathematical models in a minority of research papers. Examples of these papers are Ferrer and Whybark (2001) and Kongar and Gupta (2002) which categorise cores into two groups: usable and unusable parts, while Ullerich (2014) is the only one that considers a detailed definition of cores which include hazardous, damaging, genuine and purity conditions. The economic factors considered by most research papers in component planning and scheduling are acquisition cost, purchasing cost, inventory cost, disassembly cost, disposal cost, recycle cost and set up cost. An exception to this trend is the study of Kongar and Gupta (2006) which consider both economic factors (profits, material sales, cost) and environmental factors (the number of disposed items). Although RMRP was commonly used between 1997 and 2001, the heuristic method was the most frequently used (7 of 13) method among others between 1997 and 2015 when dealing with component planning and scheduling.

In conclusion, there are opportunities for further research on component planning and scheduling as follows:

- The decision making should include incomplete disassembly, capacity constraint, adaptive sequence and fluctuating lead time since these factors affect decision making in the real practice of remanufacturing.

- Core condition can be defined in different ways. For example, obsolescence in real practice decision making could be one of the new criteria for core condition.

- Multiple objective models including economic, environmental and engineering perspectives could complete the area of component planning and scheduling by considering product commonality and multiple products in remanufacturing and reverse logistics.

[Table 7. Component planning and scheduling by considering product commonality and multiple products in reverse logistics]

\subsection{Level of disassembly}

Since the potential value of recovered products/components often outweighs the cost of disassembly (Priyono, 2015), full disassembly is usually more cost-effective for high-value products/components such as those used in the automotive industry. Apart from the salvage value, remanufacturing lead time 
is another reason why full disassembly is preferred. For example, if products are partly disassembled, more time will be needed to inspect each of the subassemblies and further disassembly may be required, hence lengthening the overall lead time. High-value parts such as automotive components are complex by design so it usually requires full disassembly to examine the condition of cores before making any decisions including the EOL options. Although full disassembly is not always deemed as economically efficient (Lambert, 2002, Smith and Chen, 2011), it is often case-specific depending on the trade-off between the value of remanufactured products and the cost of disassembly. The cost is comprised of: (i) tools and labour costs, (ii) material reprocessing, cost of materials and (iii) disposal costs which cover transportation and landfill costs (Zhang et al., 2004).

Factors used in deciding the level of disassembly can be categorised into three types: economic, engineering and environmental as shown in Table 8. Most papers studied disassembly levels based on economic factors only such as disassembly costs (Penev and De Ron, 1996, Lambert, 1999, Meimei et al., 2002, González and Adenso-Díaz, 2005, Teunter, 2006, Lee et al., 2010). However, other factors which specify the causes and effects of disassembly are often overlooked. The reasons for disassembly are: demand rate (Kang and Hong, 2011, Rickli and Camelio, 2012), return rate (Meimei et al., 2002, Go et al., 2011) and lead time (Kang and Hong, 2011). Disassembling cores often leads to new part replacement and part disposal which are two common effects of disassembly. However, only some of the papers take replacement cost (Penev and De Ron, 1996) and disposal cost (Kang and Hong, 2011) into account. Although quality and product age are unknown factors before disassembly in real practice, they were considered in the papers in order to find the level of disassembly (Teunter, 2006, Xanthopoulos and Iakovou, 2009). Other factors which are neglected in most previous papers are multiplicity (sharing common components among the same type of products) and product commonality (sharing common components among products in the same family). These two factors can determine the part recoverability, hence, the need for disassembly. Also, there are fewer research papers which focus on environmental impacts together with economic and engineering factors. Further studies are therefore necessary to include all these factors.

[Table 8. Factors used in deciding the level of disassembly]

\subsection{Cleaning}

Cleaning is the most expensive activity according to a survey undertaken in US automotive remanufacturing sector. This is mainly because cleaning requires a high consumption of resources and labour hours (Hammond et al., 1998). Also, cleaning procedures will affect the quality, availability, remanufacturing cost and remaining life of remanufactured products (Liu et al., 2013). Cleaning in remanufacturing is different from cleaning in traditional manufacturing and maintenance. In the remanufacturing context, all parts of the product must be cleaned even though only some parts need to be repaired or remanufactured. Remanufacturers have to process a great variety of complex products in different sizes, with different materials and various surface 
contaminations while the quality of remanufactured products has to be the same as that of the Original Equipment Manufacturers' (OEMs) products. Given the uncertain and diverse application of used products and contamination, remanufacturers found that these products can be quite different from those of new products. Table 9 shows 7 factors that make cleaning difficult in remanufacturing. To reduce costs and improve cleaning performance, parts of the same category should be cleaned together (Fadeyi et al., 2017). Parts can be sorted into the same category with respect to their recovery method, materials, and contamination (Fadeyi et al., 2017). Also, remanufacturers can optimise the salvage value of used products/components by selecting the best cleaning technique.

[Table 9. Factors that make cleaning difficult in remanufacturing]

Research about cleaning in remanufacturing is relatively new since there are only a limited number of documents (10 journal papers, 1 thesis and 1 conference paper). Also, all of them were published between 2013 and 2016. These documents can be categorised into three groups. The first group is about cleaning techniques. Most papers studied supercritical CO2 (e.g. Li et al. (2016a), Liu et al. (2015) and Liu et al. (2014)). Some papers investigated ultrasonic (Chang et al., 2013) and blasting methods (Li et al., 2016a, Long et al., 2014). No paper was found to have examined thermal decomposition and chemical agents which are common cleaning methodologies in traditional manufacturing. The second group makes comparisons between cleaning techniques. The advantages and disadvantages of each cleaning technique are discussed by (Liu et al., 2013) and (Duan et al., 2014). Our paper reviews the comparisons of cleaning techniques in addition to these two papers as seen in Table 10. Li et al. (2015) compare the effects of cleaning performance between thermal decomposition and supercritical $\mathrm{CO}_{2}$ on engine components. The life cycle of each cleaning technique is compared in the study of (Peng et al., 2016). It shows that high temperature decomposition generates the largest amounts of pollution and consumes the largest resources, followed by supercritical CO2 cleaning, shot blasting, and liquid blasting cleaning. The last group of papers is about the decision factors for cleaning in remanufacturing as seen in Gamage et al.(2014).

[Table 10. Comparisons of some common cleaning techniques]

The direction of future research could optimise the choice of cleaning techniques which have received very limited attention. Also, decision making on cleaning techniques in remanufacturing depends on the experience of the remanufacturer rather than standard knowledge (Liu et al., 2013). In fact, there is often more than one cleaning technique suitable for each faulty condition of cores. Also, each technique has various positive and negative impacts on the overall remanufacturing outcome, hence decisions about the most appropriate technique are never easy. 


\subsection{Integrated decision making}

It should be noted that there are 12 papers ( 9 papers from 3.1 and 3 papers from 3.4 ) which consider integrated decision making. Table 11 summarises those papers in terms of decision types examined, decision making steps (simultaneous step /multi steps), methodology applied and decision factors considered. Our review results suggest that EOL options were mostly considered together with either disassembly level (6 papers) or purchasing new orders (6 papers), followed by EOL options with disassembly sequences (5 papers) and EOL options with core acquisition (1 paper). Decision making on EOL options in remanufacturing is always taken together with either purchasing new orders or core acquisition. When remanufacturers decide to recycle or to dispose of components, they need to purchase new or used components/products to replace those components which are unusable. Also, decisions on the level of disassembly usually affect decisions on EOL options since the reusability of cores becomes clearer after disassembly.

Since integrated decision making is complex, some previous authors have applied various methods to reduce the difficulties of modelling. For example, previous authors used and/or graphs, liaison graphs and transition matrices to make decision making simpler on disassembly sequence. Moreover, previous authors applied multi-steps in the decision making (4 of 12 papers) or applied GA/heuristics/metaheuristics ( 3 of 12 papers) to reduce computation time.

Table 11 shows that the decision factors considered in integrated decision making can be categorised into four groups: economic, engineering, environmental and legal. Some of these factors, due to their quantitative nature (e.g. monetary factors, environmental impact), are commonly used as objectives for mathematical modelling. Our review also reveals that economic factors are mostly examined (8 of 12) followed by both economic and environmental factors (4 of 12) while other factors are under-studied.

In conclusion, opportunities for further research about integrated decision making are detailed as follows:

- Considering multiple objectives could be useful for future research since the decision making involving PESTEL perspectives (political, economic, societal, technical, environmental and legal aspects) is widely successful across a number of organisations (Carpenter and Sanders, 2009).

- There is a research opportunity to consider under-studied factors since they are also found to be useful in real practice. These factors are availability, demand, quantity of components/ products, return rate, lead time, recoverability, disassembly sequence, product lifecycle, product commonality, environmental impact, recovery rate, incineration capacity, hazardous materials and maximum disposal rate.

- Further studies about integrated decision making may consider more decision types. For example, cleaning options can be considered with EOL options because cleaning performance directly affects 
both quality and availability of components which are major considerations when selecting EOL options. Also, integrated decision making between core acquisitions with EOL options could be given more attention since there are still a limited number of papers on this topic.

[Table 11. Review results about integrated decision making]

\section{Conclusion}

To the best of our knowledge, this study is the first to provide a comprehensive review of the major decisions to be taken in optimising remanufacturing outcomes. Our review reveals a number of directions for future research which can be categorised into two areas: the gaps for each major decision and the gaps for integrated decision making in the context of remanufacturing.

\subsection{Gaps for each major decision}

The major decisions include five remanufacturing activities which have different research gaps as follows: (i) For EOL options, the direction of future research should be to determine the best EOL options at the component-level which consider multiple objectives. Also, more effective and efficient methods including GA, other metaheuristics, MINLP and the subjective weighting method should be employed. (ii) For core acquisition, more attention should be paid to important yet under-studied factors. Also, further research can focus on random demand rate, return rate and quality of cores. The quality of returned cores can be measured by operational time, product life or recovery costs. (iii) For component planning and scheduling, there are research opportunities to manage the commonality of components in remanufacturing. There is a lack of papers which consider capacity constraints, adaptive sequences and fluctuating lead times. Moreover, multiple objectives should be considered including economic, environmental and engineering factors simultaneously. (iv) For the disassembly level, there are limited research papers which focus on environmental impact together with economic and engineering factors. The direction of future research should focus on multiplicity and product commonality which will help define the optimal level of disassembly. (v) For cleaning, the direction of future research should be how to select the best cleaning techniques to optimise the salvage value of used products.

\subsection{Gaps for integrated decision making}

The outcome of remanufacturing is a function of the decisions taken for all the remanufacturing activities. Given the strong correlations between decisions made for different activities, a holistic way of managing those decisions is needed, known as integrated decision making, which is a major research gap. Most of the existing studies considering multiple decision making only examine EOL options together with disassembly planning or the purchase of new orders. Therefore, to further improve the remanufacturing outcomes, future research should include more or all major decisions, e.g. selecting 
the best cleaning technique and acquiring optimal amounts of core. The best cleaning technique must also be examined because cleaning costs contribute significantly to the total remanufacturing costs and cleaning performance has a huge effect on the quality and availability of components. Also, optimal core acquisition is always decided together with EOL options in real practice, however, there are still a limited number of research papers which have studied them together. Furthermore, when making integrated decisions, economic, engineering and environmental objectives must be considered simultaneously and some of the under-studied factors should also be incorporated into the decision models.

Since this study has only reviewed the main decisions taken in remanufacturing activities, therefore, further research can review other decisions taken in different remanufacturing activities rather than core acquisition, disassembly, cleaning, reworking and reassembly. Our future research will focus on integrated decision making which combines purchasing new orders, core acquisition and EOL options.

\section{References}

Benzies, k. m., Premji, s., Hayden, k. a. \& Serrett, k. 2006. State-of-the- evidence reviews: Advantages and challenges of including grey literature. Worldviews on Evidence-Based Nursing, 3, 55-61.

Bornmann, L. \& Marx, W. 2014. How to evaluate individual researchers working in the natural and life sciences meaningfully? A proposal of methods based on percentiles of citations.(Report). Scientometrics, 98, 487.

Bornmann, L. \& Williams, R. 2017. Can the journal impact factor be used as a criterion for the selection of junior researchers? A large- scale empirical study based on ResearcherID data. Journal of Informetrics, 11, 788-799.

Bufardi, A., Gheorghe, R., Kiritsis, D. \& Xirouchakis, P. 2004. Multicriteria decision- aid approach for product end-of- life alternative selection. International Journal of Production Research, 42, 3139-3157.

Bulmus, S. C., Zhu, S. X. \& Teunter, R. 2013. Competition for cores in remanufacturing. European Journal of Operational Research.

Bulmus, S. C., Zhu, S. X. \& Teunter, R. H. 2014. Optimal core acquisition and pricing strategies for hybrid manufacturing and remanufacturing systems. International Journal of Production Research, 52, 6627-6641.

Cai, X. 2014. Optimal acquisition and production policy in a hybrid manufacturing/ remanufacturing system with core acquisition at different quality levels. European Journal of Operational Research, 233, 374-383.

Carpenter, M. A. \& Sanders, W. 2009. Strategic Management: A Dynamic Perspective : Concepts and Cases, Pearson Prentice Hall. 
Chan, J. W. K. 2008. Product end-of- life options selection: grey relational analysis approach. International Journal of Production Research, 46, 2889-2912.

Chang, Y., Bae, J. H. \& Yi, H. C. 2013. Ultrasonic cleaning of used plastic parts for remanufacturing of multifunctional digital copier. International Journal of Precision Engineering and Manufacturing, 14, 951-956.

Cho, S., Jun, H.-B. \& Kiritsis, D. 2017. Heuristic algorithms for maximising the total profit of end-oflife computer remanufacturing. International Journal of Production Research, 55, 1350-1367.

Clottey, T. 2012. Forecasting Product Returns for Remanufacturing Operations. Decision Sciences, 43, 589-615.

Clottey, T. 2016. Development and evaluation of a rolling horizon purchasing policy for cores. International Journal of Production Research, 1-11.

CRR (Centre of Remanufacturing and Reuse), 2010. Remanufacturing in the UK: A snapshot of the UK remanufacturing industry 2009 [Online]. Centre for remanufacturing and reuse. Available: http://www.remanufacturing.org.uk/pdf/story/1p342.pdf [Accessed 17/6/2018].

Depuy, G. W., Usher, J. S., Walker, R. L. \& Taylor, G. D. 2007. Production planning for remanufactured products. Production Planning \& Control, 18, 573-583.

Duan, P., Yue, W., Zhu, Y. \& Weng, J. 2014. Remanufacturing cleaning technology and its application in concrete pump truck. Key Engineering Materials, 579-580, 398-404.

Fadeyi, J. A., Monplaisir, L. \& Aguwa, C. 2017. The integration of core cleaning and product serviceability into product modularization for the creation of an improved remanufacturingproduct service system. Journal of Cleaner Production, 159, 446-455.

Falagas, M. E., Kouranos, V. D., Arencibia-Jorge, R. \& Karageorgopoulos, D. E. 2008. Comparison of SCImago journal rank indicator with journal impact factor. FASEB Journal, 22, 2623-2628.

Featherstone, R. M. 2015. Advancing knowledge of rapid reviews: An analysis of results, conclusions and recommendations from published review articles examining rapid reviews. Systematic reviews., 4.

Ferguson, M. E. 2011. A Profit- Maximizing Approach to Disposition Decisions for Product Returns. Decision Sciences, 42, 773-799.

Ferrer, G. \& Whybark, D. C. 2001. Material Planning For A Remanufacturing Facility. Production and Operations Management, 10, 112-124.

Galbreth, M. R. \& Blackburn, J. D. 2006. Optimal Acquisition and Sorting Policies for Remanufacturing. Production and Operations Management, 15, 384-392.

Gamage, J. R. 2014. Insights into the importance and challenges of the cleaning operation in automotive remanufacturing. Thesis [M. Phil] -- University of Strathclyde, 2014.

Ghazalli, Z. \& Murata, A. 2011. Development of an AHP-CBR evaluation system for remanufacturing: end-of- life selection strategy. International Journal of Sustainable Engineering, 4, 2-15. 
Go, T. F., Wahab, D. A., Rahman, M. N. A., Ramli, R. \& Azhari, C. H. 2011. Disassemblability of endof- life vehicle: a critical review of evaluation methods. Journal of Cleaner Production, 19, 1536-1546.

González, B. \& Adenso-Díaz, B. 2005. A bill of materials- based approach for end-of- life decision making in design for the environment. International Journal of Production Research, 43, 20712099.

Guide, V. D. R. 2000. Production planning and control for remanufacturing: industry practice and research needs. Journal of Operations Management, 18, 467-483.

Guide, V. D. R., Jr., Teunter, R. H. \& Van Wassenhove, L. N. 2003. Matching demand and supply to maximize profits from remanufacturing. Manufacturing \& Service Operations Management, 5, 303.

Guide, V. D. R. \& Wassenhove, L. N. 2001. MANAGING PRODUCT RETURNS FOR REMANUFACTURING. Production and Operations Management, 10, 142-155.

Gupta, S. M. \& Taleb, K. N. 1994. Scheduling disassembly. International Journal of Production Research, 32, 1857-1866.

Hammond, R., Amezquita, T. \& Bras, B. 1998. Issues in the automotive parts remanufacturing industry: a discussion of results from surveys performed among remanufacturers. International Journal of Engineering Design and Automation - Special Issue on Environmentally Conscious Design and Manufacturing, 4, 27-46.

Han, S., Dong, M., Lu, S., Leung, S. \& Lim, M. 2013. Production planning for hybrid remanufacturing and manufacturing system with component recovery. The Journal of the Operational Research Society, 64, 1447-1460.

Hu, Y., Liu, S., Lu, H. \& Zhang, H. 2014. Remaining Useful Life Assessment and its Application in the Decision for Remanufacturing. Procedia CIRP, 15, 212-217.

Ian, G., Goodall, P., Peng, Y., Palmer, C., West, A., Conway, P., Mascolo, J. \& Dettmer, F. 2015. Performance measurement and KPIs for remanufacturing. Journal of Remanufacturing, 2015, Vol.5(1), pp.1-17, 5.

Ijomah, W. 2002. A model- based definition of the generic remanufacturing business process. ProQuest Dissertations Publishing.

Ji, X., Zhang, Z., Huang, S. \& Li, L. 2015. Capacitated disassembly scheduling with parts commonality and start- up cost and its industrial application. International Journal of Production Research, $54,1-19$.

Jun, H.-B., Lee, D.-H., Kim, J.-G. \& Kiritsis, D. 2012. Heuristic algorithms for minimising total recovery cost of end-of- life products under quality constraints. International Journal of Production Research, 50, 5330-5347. 
Jun, H. B., Cusin, M., Kiritsis, D. \& Xirouchakis, P. 2007. A multi- objective evolutionary algorithm for EOL product recovery optimization: turbocharger case study. International Journal of Production Research, 45, 4573-4594.

Kang, C. M. \& Hong, Y. S. 2011. Dynamic disassembly planning for remanufacturing of multiple types of products. International Journal of Production Research, 1-13.

Karaulova, T. \& Bashkite, V. 2016. Decision- making framework for used industrial equipment. Engineering Economics, 27, 23-31.

Kim, H. J., Lee, D. H. \& Xirouchakis, P. 2006a. Two-phase heuristic for disassembly scheduling with multiple product types and parts commonality. International Journal of Production Research, 44, 195-212.

Kim, H. J., Lee, D. H. \& Xirouchakis, P. 2007. Disassembly scheduling: literature review and future research directions. International Journal of Production Research, 45, 4465-4484.

Kim, H. J., Lee, D. H., Xirouchakis, P. \& Züst, R. 2003. Disassembly Scheduling with Multiple Product Types. CIRP Annals - Manufacturing Technology, 52, 403-406.

Kim, K., Song, I., Kim, J. \& Jeong, B. 2006b. Supply planning model for remanufacturing system in reverse logistics environment. Computers \& Industrial Engineering, 51, 279-287.

Kongar, E. \& Gupta, S. M. 2002. A multi- criteria decision making approach for disassembly-to- order systems. Journal of Electronics Manufacturing, 11, 171-183.

Kongar, E. \& Gupta, S. M. 2006. Disassembly to order system under uncertainty. Omega, 34, 550-561.

Krikke, H. R., Van Harten, A. \& Schuur, P. C. 1998. On a medium term product recovery and disposal strategy for durable assembly products. International Journal of Production Research, 36, 111 140.

Krupp, J. A. G. 1993. Structuring bills of material for automotive remanufacturing. Production and Inventory Management Journal, 34, 46-52.

Kwak, M. 2015. Planning demand- and legislation- driven remanufacturing for a product family: A model for maximizing economic and environmental potential. Industrial Engineering and Management Systems, 14, 159-174.

Kwak, M. \& Kim, H. 2016. Modeling the time - varying advantages of a remanufactured product: Is "reman" better than "brand new"? Journal of Mechanical Design, Transactions of the ASME, 138.

Lambert, A. J. D. 1999. Linear programming in disassembly/ clustering sequence generation. Computers \& Industrial Engineering, 36, 723-738.

Lambert, A. J. D. 2002. Determining optimum disassembly sequences in electronic equipment. Computers \& Industrial Engineering, 43, 553-575.

Langella, I. M. 2007. Heuristics for demand- driven disassembly planning. Computers and Operations Research, 34, 552-577. 
Lechner, G. \& Reimann, M. 2014. Impact of product acquisition on manufacturing and remanufacturing strategies. Production \& Manufacturing Research, 2, 831-859.

Lee, D. H., Kim, H. J., Choi, G. \& Xirouchakis, P. 2004. Disassembly scheduling: Integer programming models. Proceedings of the Institution of Mechanical Engineers, Part B: Journal of Engineering Manufacture, 218, 1357-1372.

Lee, H. B., Cho, N. W. \& Hong, Y. S. 2010. A hierarchical end-of- life decision model for determining the economic levels of remanufacturing and disassembly under environmental regulations. Journal of Cleaner Production, 18, 1276-1283.

Lee, S. G., Lye, S. W. \& Khoo, M. K. 2001. A Multi- Objective Methodology for Evaluating Product End-of- Life Options and Disassembly. Int J Adv Manuf, 18, 148-156.

Li, M. Z., Liu, W. W., Qing, X. C., Yu, Y., Liu, L. H., Tang, Z. J., Wang, H. J., Dong, Y. Z. \& Zhang, H. C. 2016a. Feasibility study of a new approach to removal of paint coatings in remanufacturing. Journal of Materials Processing Technology, 234, 102-112.

Li, M. Z., Liu, W. W., Short, T., Qing, X. C., Dong, Y. Z., He, Y. M. \& Zhang, H. C. 2015. Pretreatment of remanufacturing cleaning by use of supercritical $\mathrm{CO} 2$ in comparison with thermal cleaning. Clean Technologies and Environmental Policy, 17, 1563-1572.

Li, W., Bai, H., Yin, J. \& Xu, H. 2016b. Life cycle assessment of end-of- life vehicle recycling processes in China - take Corolla taxis for example. Journal of Cleaner Production, 117, 176-187.

Lisa, H., Robin, F., Megan, N., Kassi, S., Donna, M. D. \& Ben, V. 2017. Grey literature in systematic reviews: a cross- sectional study of the contribution of non- English reports, unpublished studies and dissertations to the results of meta-analyses in child- relevant reviews. $B M C$ Medical Research Methodology, 17, 1-11.

Liu, M., Liu, C., Xing, L., Liu, Z., Li, X. \& Lin, L. 2016. Assembly process control method for remanufactured parts with variable quality grades. Int J Adv Manuf Technol, 85, 1471-1481.

Liu, W. W., Li, M. Z., Short, T., Qing, X. C., He, Y. M., Li, Y. Z., Liu, L. H., Zhang, H. \& Zhang, H. C. 2015. Supercritical carbon dioxide cleaning of metal parts for remanufacturing industry. Journal of Cleaner Production, 93, 339-346.

Liu, W. W., Zhang, B., Li, M. Z., Li, Y. \& Zhang, H. C. 2013. Study on remanufacturing cleaning technology in mechanical equipment remanufacturing process.

Liu, W. W., Zhang, B., Li, Y. Z., He, Y. M. \& Zhang, H. C. 2014. An environmentally friendly approach for contaminants removal using supercritical $\mathrm{CO} 2$ for remanufacturing industry. Applied Surface Science, 292, 142-148.

Long, Y. Y., Li, J. Z., Timmer, D. H., Jones, R. E. \& Gonzalez, M. A. 2014. Modeling and optimization of the molten salt cleaning process. Journal of Cleaner Production, 68, 243-251.

Lu, Y. 2009. Optimal Acquisition and Sorting Policies for Remanufacturing over single and Multiple Periods. Master of Science in Industrial Engineering and Operations Research, University of Massachusetts Amherst 
Ma, Y.-S., Jun, H.-B., Kim, H.-W. \& Lee, D.-H. 2011. Disassembly process planning algorithms for end-of-life product recovery and environmentally conscious disposal. International Journal of Production Research, 49, 7007-7027.

Mashhadi, A. \& Behdad, S. 2017. Optimal sorting policies in remanufacturing systems: Application of product life- cycle data in quality grading and end-of- use recovery. Journal of Manufacturing Systems, 43, 15-24.

Mcauley, L., Pham, B., Tugwell, P. \& Moher, D. 2000. Does the inclusion of grey literature influence estimates of intervention effectiveness reported in meta-analyses? Lancet, 356, 1228-1231.

Mckenna, R., Reith, S., Cail, S., Kessler, A. \& Fichtner, W. 2013. Energy savings through direct secondary reuse: an exemplary analysis of the German automotive sector. Journal of Cleaner Production, 52, 103-112.

Meimei, G., Mengchu, Z. \& Caudill, R. J. 2002. Integration of disassembly leveling and bin assignment for demanufacturing automation. Robotics and Automation, IEEE Transactions on, 18, 867874.

Meng, K., Lou, P., Peng, X. \& Prybutok, V. 2016a. A hybrid approach for performance evaluation and optimized selection of recoverable end-of- life products in the reverse supply chain. Computers \& Industrial Engineering, 98, 171-184.

Meng, K., Lou, P., Peng, X. \& Prybutok, V. 2016b. An improved co- evolutionary algorithm for green manufacturing by integration of recovery option selection and disassembly planning for endof-life products. International Journal of Production Research, 54, 5567-5593.

Meng, K., Lou, P., Peng, X. \& Prybutok, V. 2017a. Multi- objective optimization decision- making of quality dependent product recovery for sustainability. International Journal of Production Economics, 188, 72-85.

Meng, K., Lou, P., Peng, X. \& Prybutok, V. 2017b. Quality- driven recovery decisions for used components in reverse logistics. International Journal of Production Research, 55, 4712-4728.

Merli, R., Preziosi, M. \& Acampora, A. 2018. How do scholars approach the circular economy? A systematic literature review. Journal of Cleaner Production, 178, 703-722.

Mitra, S. 2015. Optimal pricing and core acquisition strategy for a hybrid manufacturing/ remanufacturing system. International Journal of Production Research, 54, 1-18.

Morgan, S. D. \& Gagnon, R. J. 2013. A systematic literature review of remanufacturing scheduling. International Journal of Production Research, 51, 4853-4879.

Murayama, T. \& Shu, L. H. 2001. Treatment of reliability for reuse and remanufacture. USA.

Mutha, A., Bansal, S. \& Guide, V. D. R. 2016. Managing Demand Uncertainty through Core Acquisition in Remanufacturing. Production and Operations Management, 25, 1449-1464.

Nenes, G. \& Nikolaidis, Y. 2012. A multi- period model for managing used product returns. International Journal of Production Research, 50, 1360-1376. 
Omwando, T. A., Otieno, W. A., Farahani, S. \& Ross, A. D. 2018. A Bi- Level fuzzy analytical decision support tool for assessing product remanufacturability. Journal of Cleaner Production, 174, 1534-1549.

Ondemir, O. \& Gupta, S. M. 2014a. A multi- criteria decision making model for advanced repair-toorder and disassembly-to- order system. European Journal of Operational Research, 233, 408419.

Ondemir, O. \& Gupta, S. M. 2014b. Quality management in product recovery using the Internet of Things: An optimization approach. Computers in Industry, 65, 491-504.

Paez, A. 2017. Gray literature: An important resource in systematic reviews. Journal of evidencebased medicine., 10, 233-240.

Pazoki, M. \& Abdul-Kader, W. 2016. Optimal disposition decisions for a remanufacturing system considering time value of products. Computers \& Industrial Engineering, 99, 124-136.

Penev, K. D. \& De Ron, A. J. 1996. Determination of a disassembly strategy. International Journal of Production Research, 34, 495-506.

Peng, S., Li, T., Tang, Z., Shi, J. \& Zhang, H. 2016. Comparative life cycle assessment of remanufacturing cleaning technologies. Journal of Cleaner Production, 137, 475-489.

Pokharel, S. \& Liang, Y. 2012. A model to evaluate acquisition price and quantity of used products for remanufacturing. International Journal of Production Economics, 138, 170-176.

Priyono, A. 2015. A strategic operations framework for disassembly in remanufacturing. Thesis [Ph. D] -- University of Strathclyde, 2015.

Qian, X. F., Li, X., Xu, S. \& Lu, W. F. 2015. Critical component life prediction and cost estimation for decision support in remanufacturing.

Rickli, J. L. \& Camelio, J. A. 2012. Multi- objective partial disassembly optimization based on sequence feasibility. Journal of Manufacturing Systems.

Robotis, A., Boyaci, T. \& Verter, V. 2012. Investing in reusability of products of uncertain remanufacturing cost: The role of inspection capabilities. International Journal of Production Economics, 140, 385-395.

Sánchez-meca, J. 2010. Cómo realizar una revisión sistemática y un meta-análisis. Aula abierta, 38, 53-64.

Seidi, M. \& Kimiagari, A. M. 2010. A hybrid genetic algorithm- neural network approach for pricing cores and remanufactured cores. South African Journal of Industrial Engineering, 21, 131-148.

Shi, J., Zhang, G. \& Sha, J. 2011a. Optimal production and pricing policy for a closed loop system. Resources, Conservation \& Recycling, 55, 639-647.

Shi, J., Zhang, G. \& Sha, J. 2011b. Optimal production planning for a multi- product closed loop system with uncertain demand and return. Computers and Operations Research, 38, 641-650. 
Shokohyar, S., Mansour, S. \& Karimi, B. 2014. A model for integrating services and product EOL management in sustainable product service system ( S- PSS). Journal of Intelligent Manufacturing, 25, 427-440.

Smith, S. S. \& Chen, W.-H. 2011. Rule- based recursive selective disassembly sequence planning for green design. Advanced Engineering Informatics, 25, 77-87.

Steeneck, D. W. \& Sarin, S. C. 2017. Determining end-of- life policy for recoverable products. International Journal of Production Research, 55, 5782-5800.

Suárez, E., Calvo-Mora, A., Roldán, J. L. \& Periáñez-Cristóbal, R. 2017. Quantitative research on the EFQM excellence model: A systematic literature review (1991-2015). European research on management and business economics, 23, 147-156.

Taleb, K. N. \& Gupta, S. M. 1997. Disassembly of multiple product structures. Computers \& Industrial Engineering, 32, 949-961.

Taleb, K. N., Gupta, S. M. \& Brennan, L. 1997. Disassembly of complex product structures with parts and materials commonality. Production Planning \& Control, 8, 255-269.

Teunter, R. H. 2006. Determining optimal disassembly and recovery strategies. Omega, 34, 533-537.

Teunter, R. H. \& Flapper, S. D. P. 2011. Optimal core acquisition and remanufacturing policies under uncertain core quality fractions. European Journal of Operational Research, 210, 241-248.

Ullerich, C. 2014. Advanced disassembly planning flexible, price-quantity dependent, and multi-period planning approaches / [internet resource], Wiesbaden, Ph. D.] --Technische Universität Dresden, 2013.

Vercraene, S., Gayon, J.-P. \& Flapper, S. D. 2014. Coordination of manufacturing, remanufacturing and returns acceptance in hybrid manufacturing/ remanufacturing systems. International Journal of Production Economics, 148, 62-70.

Vinodh, S., Praveen Kumar, R. \& Nachiappan, N. 2012. Disassembly modeling, planning, and leveling for a cam- operated rotary switch assembly: A case study. International Journal of Advanced Manufacturing Technology, 62, 789-800.

Wadhwa, S., Madaan, J. \& Chan, F. T. S. 2009. Flexible decision modeling of reverse logistics system: A value adding MCDM approach for alternative selection. Robotics and Computer Integrated Manufacturing, 25, 460-469.

Wang, W., Mo, D. Y., Wang, Y. \& Tseng, M. M. 2016. Assessing the cost structure of component reuse in a product family for remanufacturing. J Intell Manuf.

Wei, S. \& Tang, O. 2014. Real option approach to evaluate cores for remanufacturing in service markets. International Journal of Production Research, 53, 1-15.

Wei, S., Tang, O. \& Sundin, E. 2015. Core ( product) Acquisition Management for remanufacturing: a review. Journal of Remanufacturing, 5, 1-27.

Xanthopoulos, A. \& Iakovou, E. 2009. On the optimal design of the disassembly and recovery processes. Waste Management, 29, 1702-1711. 
Xiang Li, S., Yongjian Li, S. \& Saghafian, S. 2013. A Hybrid Manufacturing/Remanufacturing System With Random Remanufacturing Yield and Market- Driven Product Acquisition. Engineering Management, IEEE Transactions on, 60, 424-437.

Xie, J. P., Li, Z. J., Yao, Y. \& Liang, L. 2015. Dynamic acquisition pricing policy under uncertain remanufactured-product demand. Industrial Management \& Data Systems, 115, 521-540.

$\mathrm{Xu}, \mathrm{X} .2012$. Optimal policies in hybrid manufacturing/ remanufacturing systems with random pricesensitive product returns. International Journal of Production Research, 50, 6978-6999.

Yang, C.-H., Bao, X.-Y., Song, C. \& Liu, H.-B. 2016a. Optimal acquisition policy in remanufacturing systems with quantity discount and carbon tax scheme/Optimalna politika akvizicije u sustavima preradbe s diskontom na kolicinu i planom poreza na ugljik.(Original scientific paper /Izvorni znanstveni clanak). Tehnicki Vjesnik - Technical Gazette, 23, 1073.

Yang, C.-H., Liu, H.-B., Ji, P. \& Ma, X. 2016b. Optimal acquisition and remanufacturing policies for multi- product remanufacturing systems. Journal of Cleaner Production, 135, 1571-1579.

Yang, C.-H., Wang, J. \& Ji, P. 2014. Optimal acquisition policy in remanufacturing under general core quality distributions. International Journal of Production Research, 1-14.

Yang, S., Nasr, N., Ong, S. \& Nee, A. 2016c. A holistic decision support tool for remanufacturing: endof- life ( EOL) strategy planning. Adv. Manuf., 4, 189-201.

Yang, S., Ong, S. \& Nee, A. 2015. EOL strategy planning for components of returned products. Int J Adv Manuf Technol, 77, 991-1003.

Zhang, H. C., Li, J., Shrivastava, P., Whitley, A. \& Merchant, M. E. 2004. A Web- Based System For Reverse Manufacturing And Product Environmental Impact Assessment Considering End-OfLife Dispositions. CIRP Annals - Manufacturing Technology, 53, 5-8.

Zhou, S. \& Yu, Y. 2011. Optimal Product Acquisition, Pricing, and Inventory Management for Systems with Remanufacturing. Operations Research, 59, 514-521,534.

Ziout, A., Azab, A. \& Atwan, M. 2014. A holistic approach for decision on selection of end-of- life products recovery options. Journal of Cleaner Production, 65, 497-516.

Östlin, J. 2008. On Remanufacturing Systems: Analysing and Managing Material Flows and Remanufacturing Processes. Linköping University. 


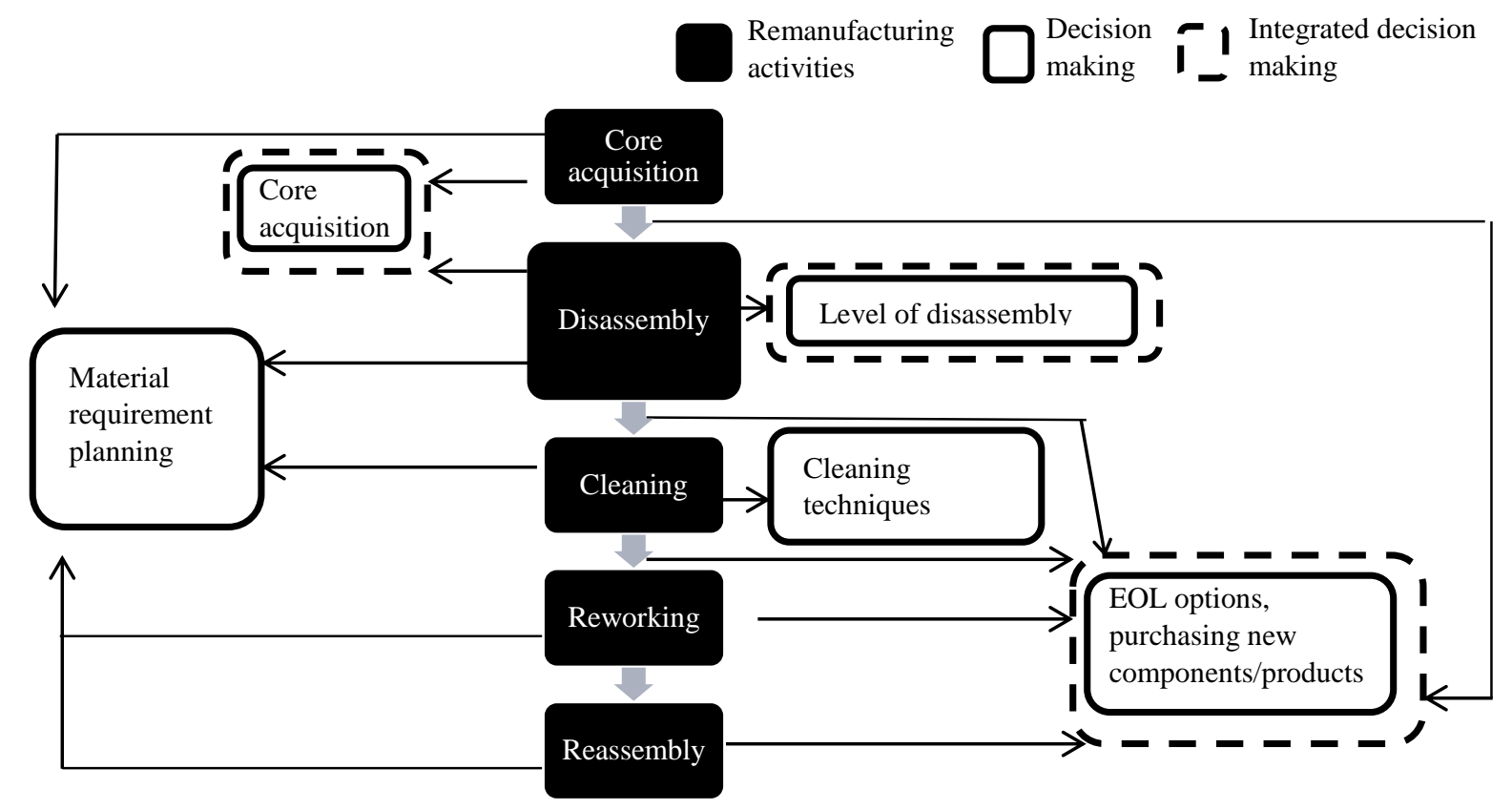

Figure 1 Streams of decision making regarding remanufacturing activities

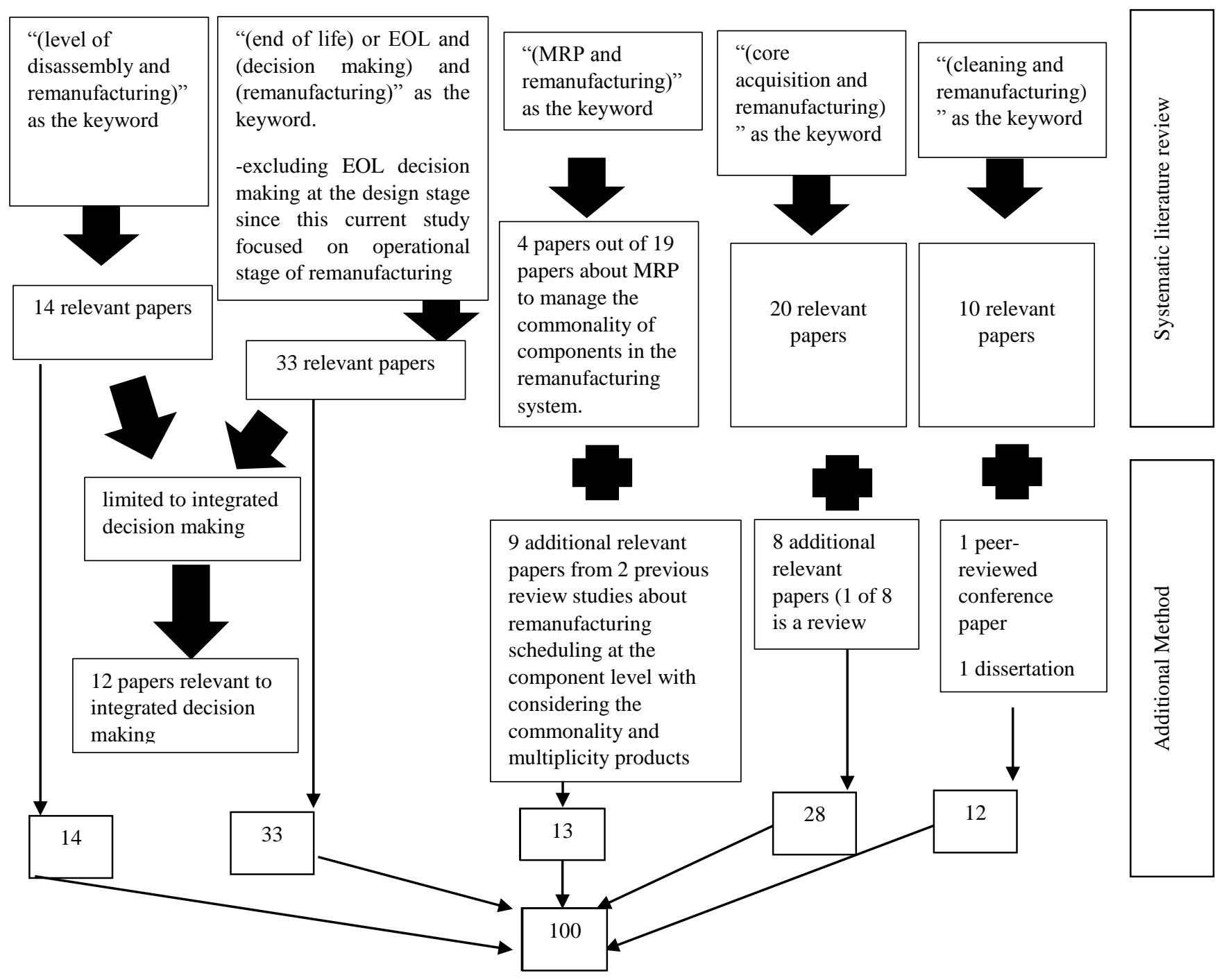

Figure 2 Paper selection 


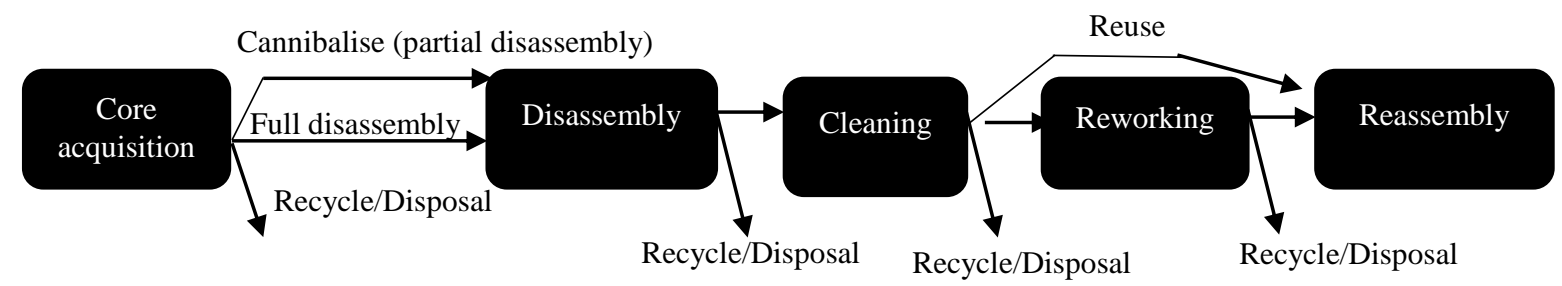

Figure 3. Selection of EOL options for different remanufacturing activities

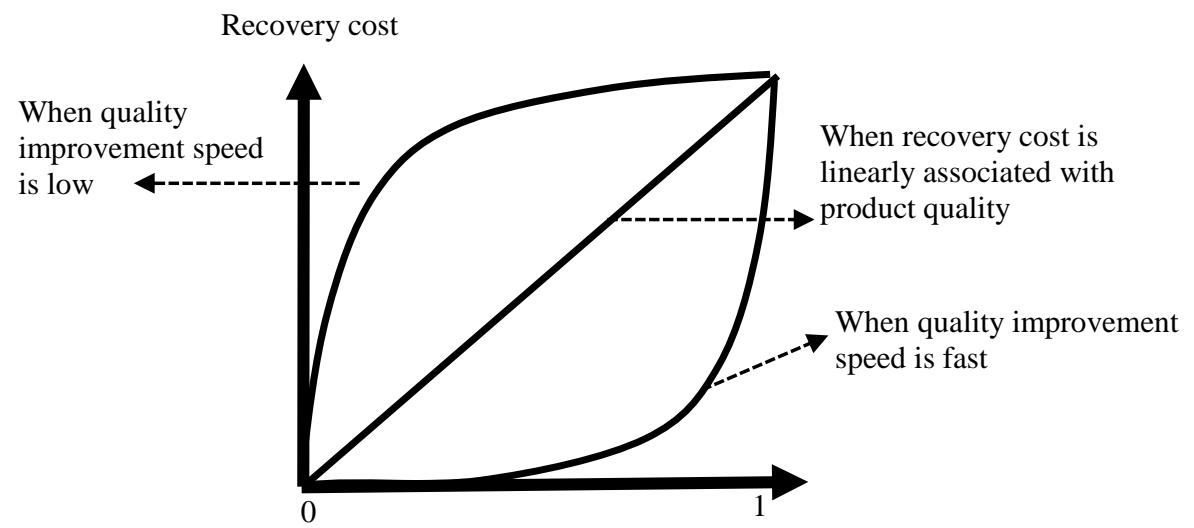

Figure 4. The relationship between recovery cost and quality (Jun et al., 2007)

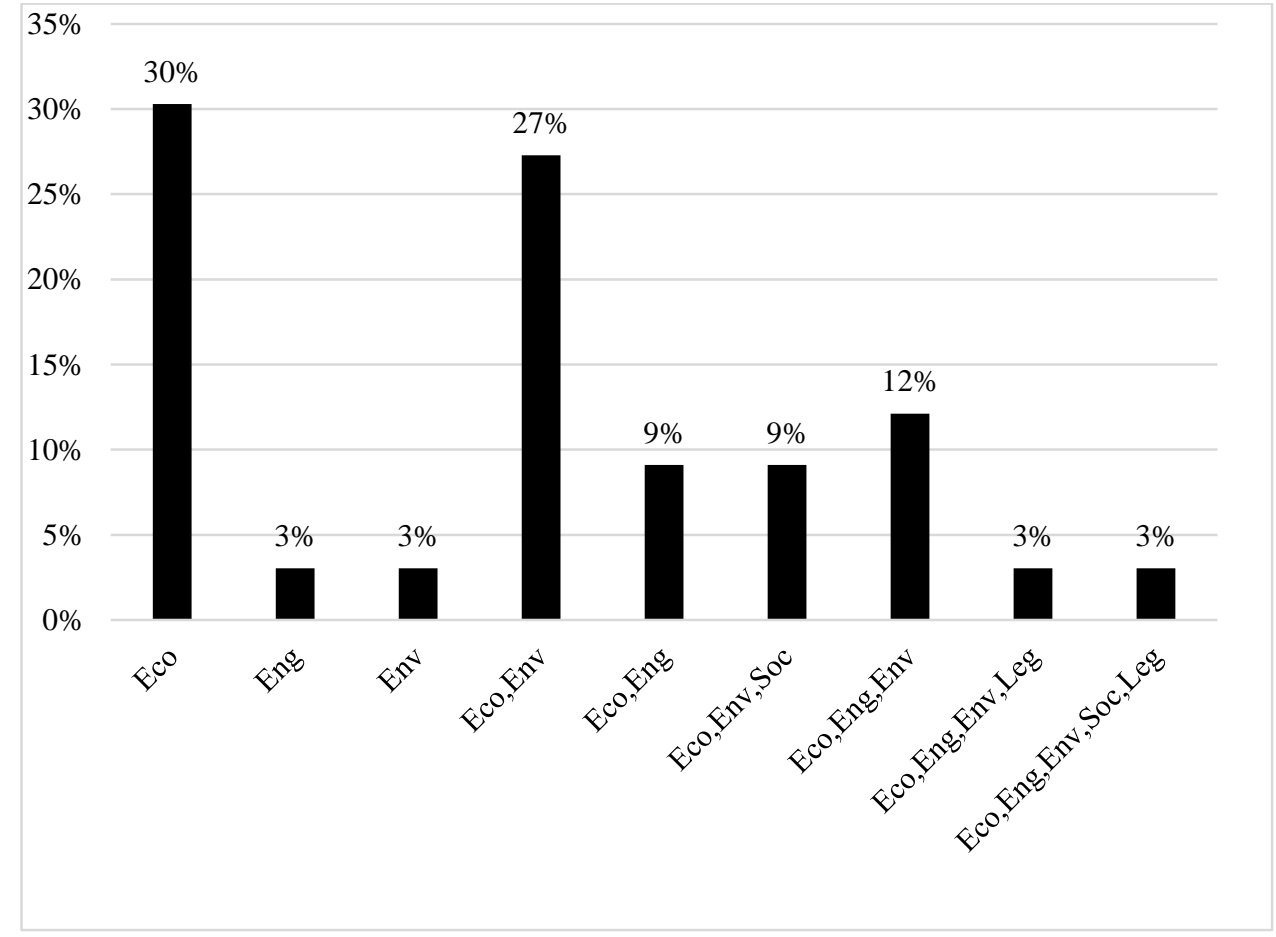

Figure 5. Percentage of papers by objectives

Eco $=$ Economic, Eng $=$ Engineering, Env $=$ Environmental, Soc $=$ Social, Leg $=$ Legal 


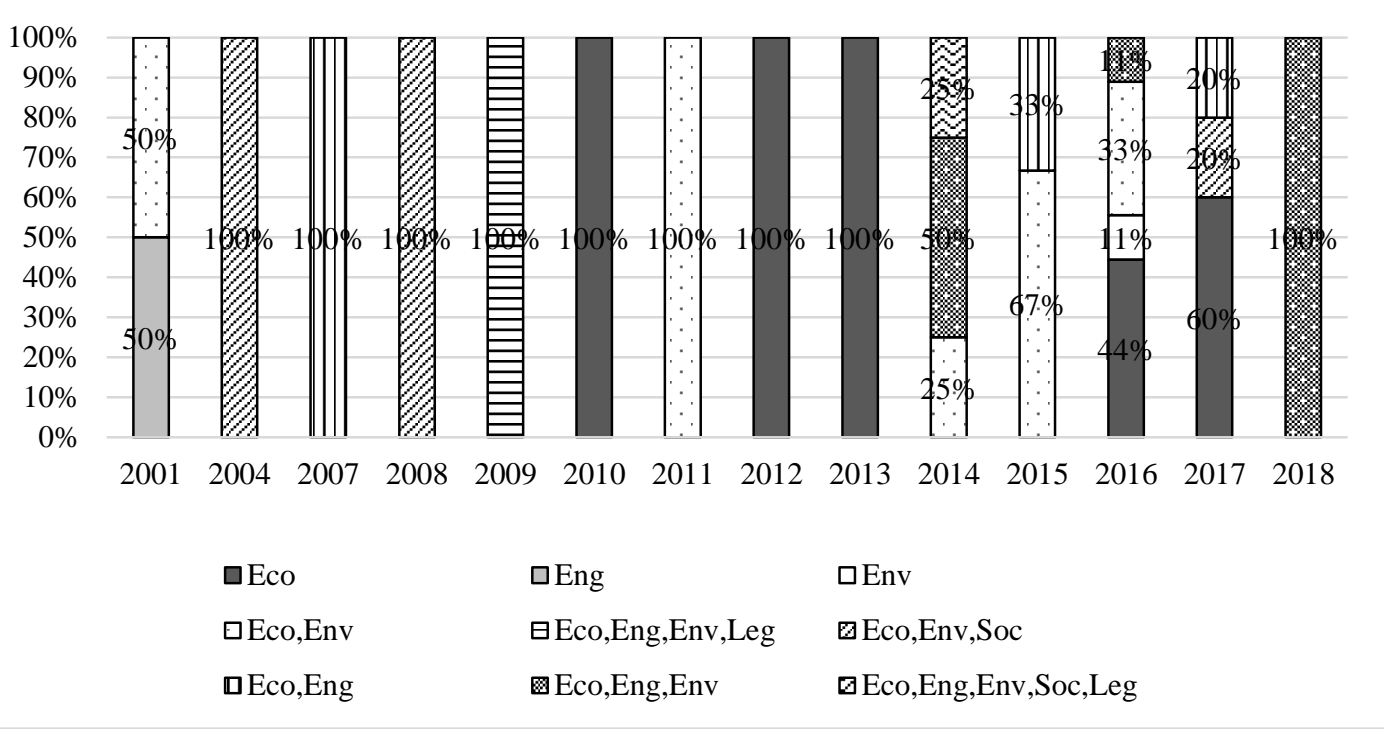

Figure 6. Percentage of papers by objectives for each publication year

Eco $=$ Economic, Eng $=$ Engineering, Env $=$ Environmental, Soc $=$ Social, Leg $=$ Legal

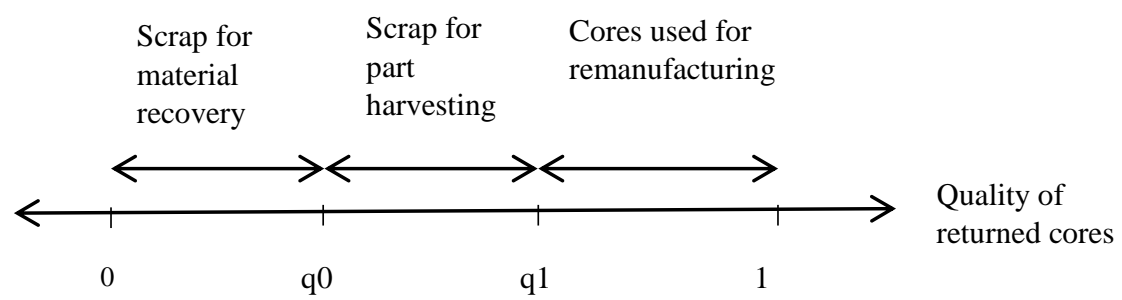

Figure 7. The classification of returned cores adopted by Ferguson (2011) 
Table 1. List of review articles

\begin{tabular}{|c|c|c|c|c|c|}
\hline Review article & Review topic & $\begin{array}{l}\text { Chosen by } \\
\text { SJR }\end{array}$ & $\begin{array}{c}\text { Cited by Q1 } \\
\text { and Q2 papers }\end{array}$ & $\begin{array}{c}\text { Type } \\
\text { of articles }\end{array}$ & Description \\
\hline Wei et al., 2015 & Core acquisition & & $\checkmark$ & Journal paper & $\begin{array}{l}\text { Core acquisition management in } \\
\text { remanufacturing. }\end{array}$ \\
\hline Ullerich,2014 & \multirow{2}{*}{ MRP } & & $\checkmark$ & Book & \multirow{2}{*}{$\begin{array}{l}\text { Remanufacturing scheduling at } \\
\text { the component level considering } \\
\text { the commonality and multiplicity } \\
\text { of products }\end{array}$} \\
\hline $\begin{array}{l}\text { Morgan and } \\
\text { Gagnon, } 2013\end{array}$ & & $\checkmark$ & $\checkmark$ & Journal paper & \\
\hline Liu et al., 2013 & \multirow[t]{2}{*}{ Cleaning } & & $\checkmark$ & $\begin{array}{l}\text { Conference } \\
\text { paper } \\
\text { (grey literature) }\end{array}$ & $\begin{array}{l}\text { Disadvantages and advantages of } \\
\text { cleaning techniques in } \\
\text { remanufacturing. }\end{array}$ \\
\hline Gamage, 2014 & & & & $\begin{array}{l}\text { Dissertation } \\
\text { (grey literature) }\end{array}$ & $\begin{array}{l}\text { Factors that affect the difficulty of } \\
\text { cleaning in remanufacturing }\end{array}$ \\
\hline
\end{tabular}

Table 2. Other EOL options discussed in the literature

\begin{tabular}{|l|l|}
\hline \multicolumn{1}{|c|}{ Other EOL options } & \multicolumn{1}{c|}{ References } \\
\hline Reconditioning & Jun et al., 2007, Shokohyar et al., 2014, Yang et al., 2015 \\
\hline Dismantling/Disassembly & Ondemir and Gupta, 2014a, Omwando et al., 2018, Meng et al., 2017a \\
\hline Refurbishment & Meng et al., 2017b, Mashhadi and Behdad, 2017, Ziout et al., 2014 \\
\hline Repair & Qian et al., 2015, Liu et al., 2016, Ziout et al., 2014 \\
\hline Salvage & Pazoki and Abdul-Kader, 2016, Steeneck and Sarin, 2017 \\
\hline Incineration & Ziout et al., 2014, Chan, 2008, Bufardi et al., 2004 \\
\hline Resale & Meng et al., 2016a, Ziout et al., 2014 \\
\hline Cannibalisation & Karaulova and Bashkite, 2016, Wadhwa et al., 2009 \\
\hline
\end{tabular}

Table 3. Decision makings in EOL options

\begin{tabular}{|c|c|c|c|c|c|c|c|c|c|c|c|c|c|c|c|}
\hline \multirow[b]{2}{*}{ References } & \multirow[b]{2}{*}{ Products } & \multirow[b]{2}{*}{$\begin{array}{l}\text { Level of } \\
\text { decision }\end{array}$} & \multicolumn{3}{|c|}{ Methods } & \multicolumn{3}{|c|}{$\begin{array}{l}\text { Economic } \\
\text { factors }\end{array}$} & \multicolumn{4}{|c|}{ Engineering factors } & \multirow[b]{2}{*}{ 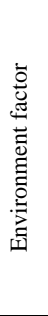 } & \multirow[b]{2}{*}{ 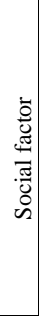 } & \multirow[b]{2}{*}{ 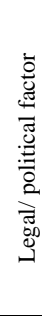 } \\
\hline & & & $\begin{array}{l}\vec{d} \\
\dot{x} \\
\dot{\Sigma}\end{array}$ & 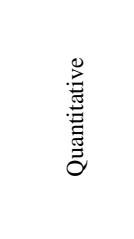 & 䔍 & 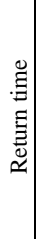 & 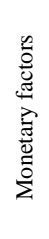 & 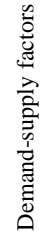 & 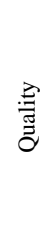 & 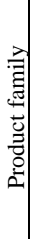 & 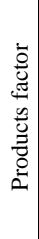 & 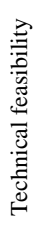 & & & \\
\hline $\begin{array}{l}\text { Murayama } \\
\text { et al., } 2001\end{array}$ & N/A & product & FMEA & & & & & & & & & $\begin{array}{l}1 \\
*\end{array}$ & & & \\
\hline $\begin{array}{l}\text { Lee et al., } \\
2001\end{array}$ & $\begin{array}{l}\text { coffee } \\
\text { machine, } \\
\text { pager }\end{array}$ & product & & MIP, LCA & & & $\begin{array}{l}1 \\
*\end{array}$ & & & & 1 & & $\begin{array}{l}1 \\
*\end{array}$ & & \\
\hline $\begin{array}{l}\text { Bufardi et } \\
\text { al., } 2004\end{array}$ & $\begin{array}{l}\text { vacuum } \\
\text { cleaner }\end{array}$ & component & ELECTRE & & & & $\begin{array}{l}1 \\
*\end{array}$ & & & & & & $\begin{array}{l}1 \\
*\end{array}$ & $\begin{array}{l}1 \\
*\end{array}$ & \\
\hline $\begin{array}{l}\text { Jun et al., } \\
2007\end{array}$ & turbocharger & component & & $\begin{array}{l}\text { MIP, Pareto } \\
\text { optimal }\end{array}$ & & & $\begin{array}{l}1 \\
* \\
\end{array}$ & & $\begin{array}{l}1 \\
* \\
\end{array}$ & & & & & & \\
\hline Chan, 2008 & $\begin{array}{l}\text { electrical } \\
\text { shaver }\end{array}$ & component & & GRA & & & $\begin{array}{l}1 \\
*\end{array}$ & & & & & & $\begin{array}{l}1 \\
*\end{array}$ & $\begin{array}{l}1 \\
*\end{array}$ & \\
\hline $\begin{array}{l}\text { Wadhwa et } \\
\text { al., } 2009\end{array}$ & brown good & product & $\begin{array}{l}\text { Fuzzy } \\
\text { logic, } \\
\text { TOPSIS }\end{array}$ & & & & $\begin{array}{l}1 \\
*\end{array}$ & $1^{*}$ & $\begin{array}{l}1 \\
*\end{array}$ & & & & $\begin{array}{l}1 \\
*\end{array}$ & & $\begin{array}{l}1 \\
*\end{array}$ \\
\hline $\begin{array}{l}\text { Lee et al., } \\
2010\end{array}$ & Mouse & $\begin{array}{l}\text { component/ } \\
\text { subassembly/ } \\
\text { product }\end{array}$ & & MIP & HALG & & $\begin{array}{l}1 \\
*\end{array}$ & & & & & 1 & & & 1 \\
\hline $\begin{array}{l}\text { Ghazalli } \\
\text { and Murata, } \\
2011\end{array}$ & $\begin{array}{l}\text { computer, } \\
\text { telephone } \\
\text {, TV, audio } \\
\text { system }\end{array}$ & $\begin{array}{l}\text { product, part } \\
\text { and } \\
\text { component } \\
\text { level }\end{array}$ & AHP & NN & CBR & & $\begin{array}{l}1 \\
*\end{array}$ & & & & & 1 & $\begin{array}{l}1 \\
*\end{array}$ & & \\
\hline $\begin{array}{l}\text { Ma et al., } \\
2011\end{array}$ & $\begin{array}{l}\text { automatic } \\
\text { pencil, } \\
\text { telephone }\end{array}$ & $\begin{array}{l}\text { part and } \\
\text { subassembly }\end{array}$ & & $\begin{array}{l}\text { MIP, } \\
\text { Heuristic }\end{array}$ & $\begin{array}{l}\text { And/or } \\
\text { graph }\end{array}$ & & $\begin{array}{l}1 \\
*\end{array}$ & & & & & 1 & 1 & & \\
\hline $\begin{array}{l}\text { Jun et al., } \\
2012\end{array}$ & turbocharger & component & & $\begin{array}{l}\text { MINLP, } \\
\text { GA }\end{array}$ & & & $\begin{array}{l}1 \\
*\end{array}$ & & 1 & & & & & & \\
\hline $\begin{array}{l}\text { McKenna et } \\
\text { al., } 2013\end{array}$ & automotive & N/A & & $\begin{array}{l}\text { Sensitivity } \\
\text { of factors, } \\
\text { LCA } \\
\end{array}$ & & & $\begin{array}{l}1 \\
*\end{array}$ & 1 & & & & & & & \\
\hline $\begin{array}{l}\text { Ondemir } \\
\text { and Gupta, } \\
2014 \mathrm{a} \\
\end{array}$ & N/A & component & & MIP & & & $\begin{array}{l}1 \\
*\end{array}$ & & $\begin{array}{l}1 \\
*\end{array}$ & & & & $\begin{array}{l}1 \\
*\end{array}$ & & \\
\hline $\begin{array}{l}\text { Shokohyar } \\
\text { et al., } 2014\end{array}$ & Notebook & component & & $\begin{array}{l}\text { GA, } \\
\text { MINLP, } \\
\text { Pareto }\end{array}$ & & & $\begin{array}{l}1 \\
*\end{array}$ & & & & & & $\begin{array}{l}1 \\
*\end{array}$ & & \\
\hline
\end{tabular}




\begin{tabular}{|c|c|c|c|c|c|c|c|c|c|c|c|c|c|c|c|}
\hline $\begin{array}{l}\text { Ziout et al., } \\
2014\end{array}$ & fuel cell stack & component & AHP & & PESTEL & & $\begin{array}{l}1 \\
*\end{array}$ & $\begin{array}{l}1 \\
*\end{array}$ & & & $\begin{array}{l}1 \\
*\end{array}$ & $\begin{array}{l}1 \\
*\end{array}$ & $\begin{array}{l}1 \\
*\end{array}$ & $\begin{array}{l}1 \\
*\end{array}$ & $\begin{array}{l}1 \\
*\end{array}$ \\
\hline $\begin{array}{l}\text { Ondemir } \\
\text { and Gupta, } \\
2014 b\end{array}$ & N/A & component & & MIP & & & $\begin{array}{l}1 \\
*\end{array}$ & 1 & $\begin{array}{l}1 \\
*\end{array}$ & & & & $\begin{array}{l}1 \\
*\end{array}$ & & \\
\hline $\begin{array}{l}\text { Qian et al., } \\
2015\end{array}$ & Engine & component & & LCA & & & $\begin{array}{l}1 \\
*\end{array}$ & & $\begin{array}{l}1 \\
*\end{array}$ & & & & & & \\
\hline $\begin{array}{l}\text { Yang et al., } \\
2015\end{array}$ & $\begin{array}{l}\text { alternator, } \\
\text { hedge trimmer }\end{array}$ & component & & MIP & HALG & & $\begin{array}{l}1 \\
*\end{array}$ & & 1 & & & & $\begin{array}{l}1 \\
*\end{array}$ & & \\
\hline Kwak, 2015 & Alternator & component & & Pareto, MIP & & & $\begin{array}{l}1 \\
*\end{array}$ & & 1 & 1 & & & $\begin{array}{l}1 \\
*\end{array}$ & & \\
\hline $\begin{array}{l}\text { Pazoki and } \\
\text { Abdul- } \\
\text { Kader, } 2016\end{array}$ & Printer & product & & $\begin{array}{l}\text { MINLP, } \\
\text { sensitivity } \\
\text { analysis }\end{array}$ & & & $\begin{array}{l}1 \\
*\end{array}$ & & & & & 1 & & & \\
\hline $\begin{array}{l}\text { Kwak and } \\
\text { Kim, } 2016\end{array}$ & $\begin{array}{l}\text { alternator, } \\
\text { desktop }\end{array}$ & product & & MIP & & & $\begin{array}{l}1 \\
*\end{array}$ & & 1 & & & & $\begin{array}{l}1 \\
*\end{array}$ & & \\
\hline $\begin{array}{l}\text { Wang et al., } \\
2016\end{array}$ & Bulldozer & component & & MIP & & & $\begin{array}{l}1 \\
*\end{array}$ & & & 1 & & & & & \\
\hline $\begin{array}{l}\text { Liu et al., } \\
2016\end{array}$ & Engine & component & & GA & & & $\begin{array}{l}1 \\
*\end{array}$ & & 1 & & & & & & \\
\hline $\begin{array}{l}\text { Yang et al., } \\
2016 \mathrm{c}\end{array}$ & Telephone & $\begin{array}{l}\text { product and } \\
\text { component }\end{array}$ & & $\begin{array}{l}\text { GA } \\
\text { (NSGAII), } \\
\text { Pareto }\end{array}$ & & 1 & $\begin{array}{l}1 \\
*\end{array}$ & & & & & 1 & $\begin{array}{l}1 \\
*\end{array}$ & & 1 \\
\hline $\begin{array}{l}\text { Meng et al., } \\
2016 \mathrm{a}\end{array}$ & N/A & $\begin{array}{l}\text { product and } \\
\text { component }\end{array}$ & $\begin{array}{l}\text { Fuzzy } \\
\text { logic, } \\
\text { Promethee } \\
\end{array}$ & MIP & & 1 & $\begin{array}{l}1 \\
*\end{array}$ & 1 & 1 & & & 1 & $\begin{array}{l}1 \\
*\end{array}$ & & 1 \\
\hline $\begin{array}{l}\text { Meng et al., } \\
2016 \mathrm{~b}\end{array}$ & N/A & N/A & & ICA & & 1 & $\begin{array}{l}1 \\
*\end{array}$ & 1 & 1 & & & 1 & 1 & & \\
\hline $\begin{array}{l}\text { Li et al., } \\
2016 \text { b }\end{array}$ & Vehicle & component & & LCA & & & & & & & & & $\begin{array}{l}1 \\
*\end{array}$ & & \\
\hline $\begin{array}{l}\text { Karaulova } \\
\text { and } \\
\text { Bashkite, } \\
2016 \\
\end{array}$ & $\begin{array}{l}\text { truck, } \\
\text { machinery }\end{array}$ & product & & LCA, & TRIZ & & $\begin{array}{l}1 \\
*\end{array}$ & & & & & $\begin{array}{l}1 \\
*\end{array}$ & $\begin{array}{l}1 \\
*\end{array}$ & & \\
\hline $\begin{array}{l}\text { Meng et al., } \\
2017 \mathrm{a}\end{array}$ & Engine & component & & $\begin{array}{l}\text { GA } \\
\text { (NSGAII), } \\
\text { Pareto }\end{array}$ & & & $\begin{array}{l}1 \\
*\end{array}$ & & 1 & & & & $\begin{array}{l}1 \\
*\end{array}$ & $\begin{array}{l}1 \\
*\end{array}$ & \\
\hline $\begin{array}{l}\text { Meng et al., } \\
2017 b\end{array}$ & N/A & component & & PHM & & & $\begin{array}{l}1 \\
*\end{array}$ & & $\begin{array}{l}1 \\
*\end{array}$ & & & & & & \\
\hline $\begin{array}{l}\text { Mashhadi } \\
\text { and } \\
\text { Behdad, } \\
2017\end{array}$ & N/A & N/A & & $\begin{array}{l}\text { MIP, } \\
\text { clustering } \\
\text { algorithm }\end{array}$ & & & $\begin{array}{l}1 \\
*\end{array}$ & 1 & 1 & & 1 & & & 1 & \\
\hline $\begin{array}{l}\text { Cho et al., } \\
2017\end{array}$ & Computer & component & & $\begin{array}{l}\text { GA, } \\
\text { ACSA }\end{array}$ & & & $\begin{array}{l}1 \\
*\end{array}$ & 1 & 1 & & & & & & \\
\hline $\begin{array}{l}\text { Steeneck } \\
\text { and Sarin, } \\
2017\end{array}$ & N/A & product & & MIP & & & $\begin{array}{l}1 \\
*\end{array}$ & 1 & 1 & & & & & & \\
\hline $\begin{array}{l}\text { Omwando } \\
\text { et al., } 2018\end{array}$ & $\begin{array}{l}\text { power control } \\
\text { drive }\end{array}$ & product & Fuzzy logic & & & & $\begin{array}{l}1 \\
*\end{array}$ & & & & & $\begin{array}{l}1 \\
*\end{array}$ & $\begin{array}{l}1 \\
*\end{array}$ & & \\
\hline Total & & & & & & 3 & 31 & 9 & 17 & 2 & 3 & 11 & 20 & 5 & 5 \\
\hline
\end{tabular}

* = objectives , FMEA = Failure mode and effect analysis, MIP = mixed integer programming, LCA = life cycle assessment, GRA= Grey Relational Analysis, $\mathrm{HALG}=$ hierarchical attributed liaison graph, $\mathrm{AHP}=$ analytical hierarchy process, $\mathrm{NN}=$ The nearest neighbourhood algorithm, $\mathrm{CBR}=$ case-based reasoning, MINLP = mixed integer non-linear programming, GA = Genetic algorithm, ICA = Improved co- evolutionary algorithm TRIZ=Theory of Inventive Problem Solving, PHM = proportional hazard model, ACSA = an ant colony search algorithm 
Table 4. Methods used in selecting EOL options

\begin{tabular}{|c|c|c|c|c|c|c|c|c|c|c|c|c|c|c|}
\hline Method & ఠ్ & ষ্ণ & & 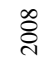 & छे & 을 & $\bar{\Xi}$ & $\stackrel{\sim}{\stackrel{N}{(}}$ & $\stackrel{m}{\stackrel{2}{\sim}}$ & $\underset{⿱ 乛}{\vec{d}}$ & $\frac{n}{2}$ & $\stackrel{\circ}{\stackrel{2}{c}}$ & $\vec{a}$ & $\stackrel{\infty}{\stackrel{ }{\sim}}$ \\
\hline Others & $\checkmark$ & $\checkmark$ & & $\checkmark$ & $\checkmark$ & $\checkmark$ & $\checkmark$ & & $\checkmark$ & $\checkmark$ & $\checkmark$ & $\checkmark$ & $\checkmark$ & \\
\hline MIP & $\checkmark$ & & $\checkmark$ & & & $\checkmark$ & & & & $\checkmark$ & $\checkmark$ & $\checkmark$ & $\checkmark$ & \\
\hline LCA & $\checkmark$ & & & & & & & & $\checkmark$ & & $\checkmark$ & $\checkmark$ & & \\
\hline Fuzzy logic & & & & & $\checkmark$ & & & & & & & $\checkmark$ & & $\checkmark$ \\
\hline Pareto & & & $\checkmark$ & & & & & & & $\checkmark$ & $\checkmark$ & $\checkmark$ & $\checkmark$ & \\
\hline Metaheuristics(GA) & & & & & & & & $\checkmark$ & & $\checkmark$ & & $\checkmark$ & $\checkmark$ & \\
\hline Metaheuristics (ICA /ACSA) & & & & & & & & & & & & $\checkmark$ & $\checkmark$ & \\
\hline MINLP & & & & & & & & $\checkmark$ & & $\checkmark$ & & $\checkmark$ & & \\
\hline AHP & & & & & & & $\checkmark$ & & & $\checkmark$ & & & & \\
\hline
\end{tabular}

Table 5. The list of papers categorised by types of demand rate and types of return rate

\begin{tabular}{|c|c|c|}
\hline & Type & References \\
\hline \multirow{3}{*}{$\begin{array}{l}\text { Demand rate of } \\
\text { remanufactured } \\
\text { products }\end{array}$} & Deterministic & $\begin{array}{l}\text { Galbreth and Blackburn, 2006, Wei and Tang, 2014, Pokharel and Liang, 2012, Kang and Hong, 2011, } \\
\text { Yang et al., } 2014\end{array}$ \\
\hline & Stochastic & $\begin{array}{l}\text { Guide et al., 2003, Galbreth and Blackburn, 2006, Teunter and Flapper, 2011, Clottey, 2012, Cai, 2014, } \\
\text { Lechner and Reimann, 2014, Yang et al., 2014, Yang et al., 2016b, Yang et al., 2016a }\end{array}$ \\
\hline & Random & Xie et al., 2015, Zhou and Yu, 2011, Clottey, 2016 \\
\hline \multirow{3}{*}{$\begin{array}{l}\text { Return rate of } \\
\text { cores }\end{array}$} & Deterministic & Wei and Tang, 2014, Kang and Hong, 2011, Xie et al., 2015 \\
\hline & Stochastic & $\begin{array}{l}\text { Xiang Li et al., 2013, Shi et al., 2011a, Shi et al., 2011b, Zhou and Yu, 2011, Xu, 2012, Guide et al., 2003, } \\
\text { Clottey, 2012, Cai, 2014, Clottey, } 2016\end{array}$ \\
\hline & Random & Zhou and Yu, 2011, Clottey, 2016 \\
\hline
\end{tabular}


Table 6. Review findings about factors and modelling approaches used in core acquisition

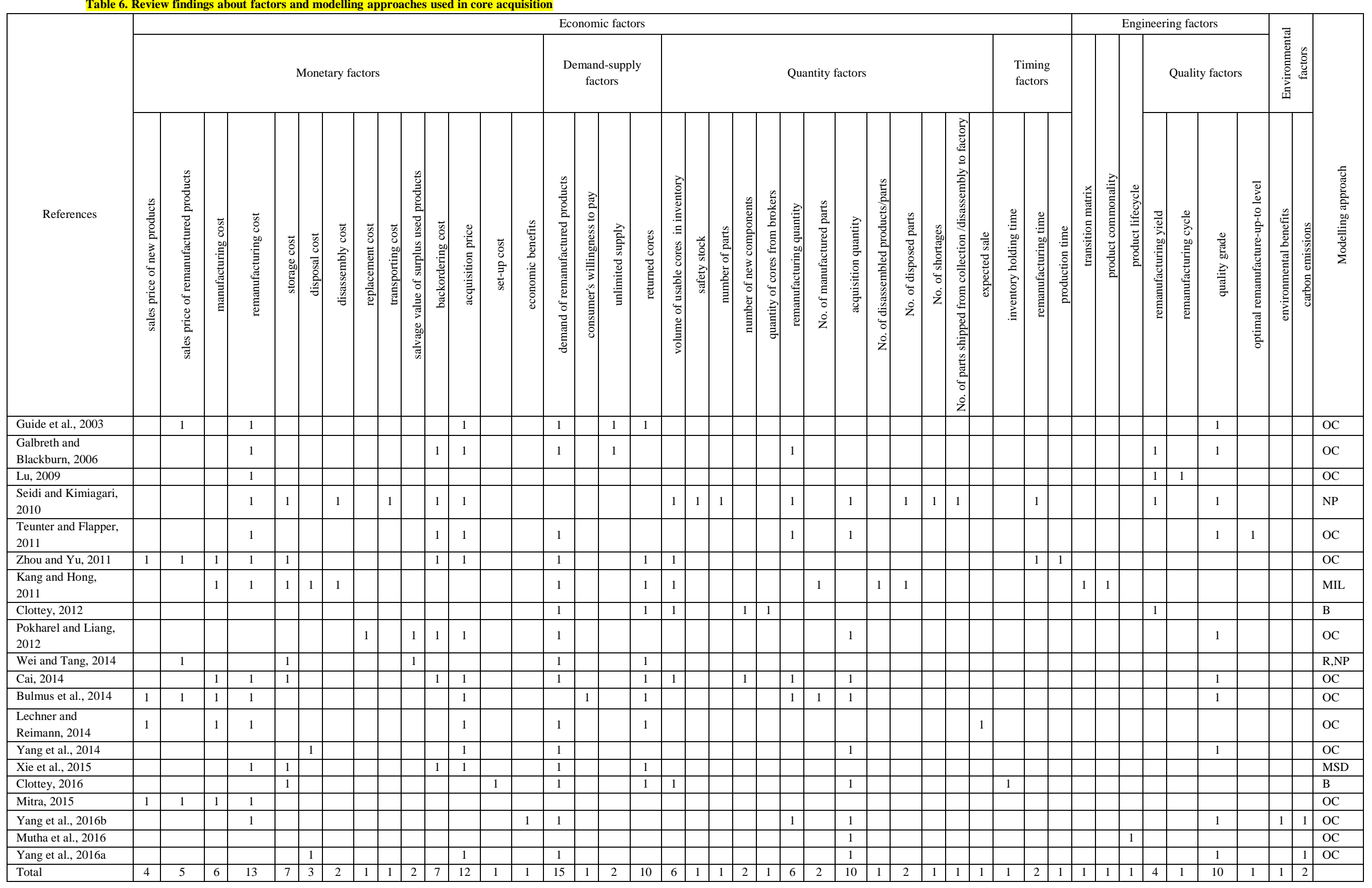

OC-optimal control, NP-non-linear programming, MIL- mixed integer linear programming, B-Bayesian estimation of distributed lag model, R- real option valuation, MSD- multi-period stochastic dynamic programming 
Table 7. Component planning and scheduling by considering product commonality and multiple products in reverse logistics

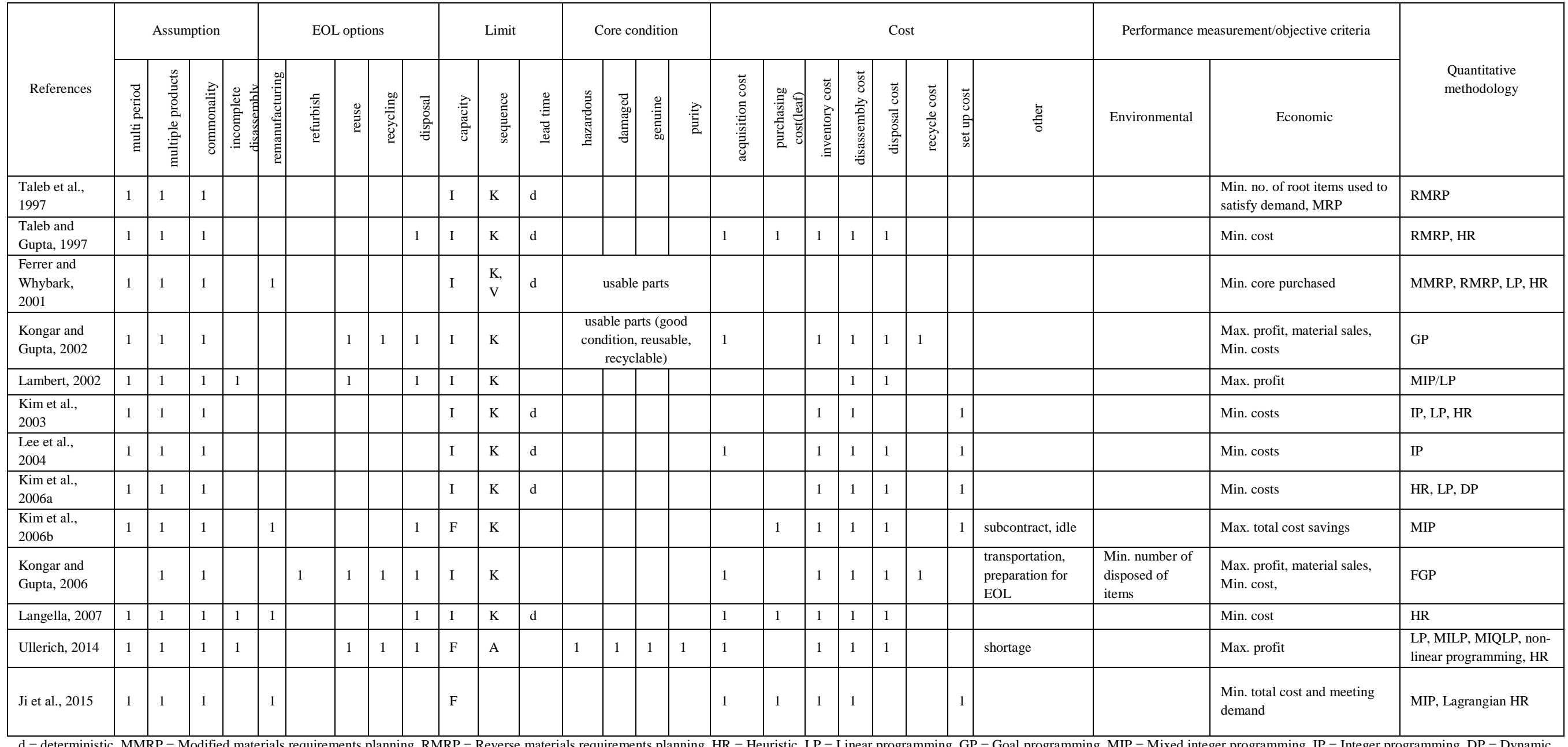

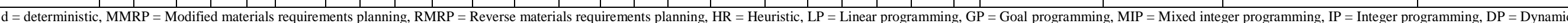
programming, FGP = Fuzzy goal programming, MILP = Mixed integer linear programming, MIQLP = Mixed integer quadratic programming with linear constraints, $I=$ Infinite, $F=$ Finite, $K=$ Known, A = Adaptive, V = Variable yield 
Table 8. Factors used in deciding the level of disassembly

\begin{tabular}{|c|c|c|c|c|c|c|c|c|c|c|c|c|c|c|c|c|c|c|c|c|c|}
\hline \multirow[b]{2}{*}{ Authors } & \multicolumn{16}{|c|}{ Economic } & \multicolumn{4}{|c|}{ Engineering } & \multirow[b]{2}{*}{ 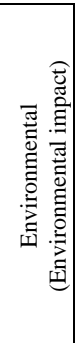 } \\
\hline & 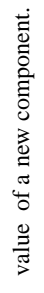 & 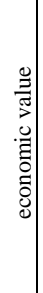 & 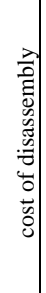 & 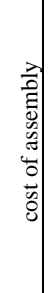 & 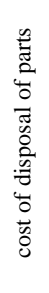 & $\begin{array}{l}0 \\
0 \\
0 \\
0 \\
00 \\
.0 \\
0 \\
0 \\
0\end{array}$ & 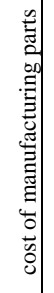 & 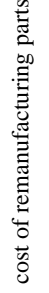 & 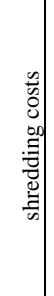 & 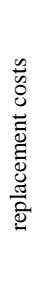 & 气 & 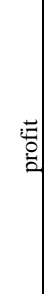 & $\begin{array}{l}\text { ज्ञ } \\
\text { : }\end{array}$ & 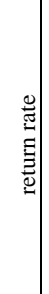 & $\begin{array}{c}\Xi \\
. \Xi \\
\Xi \\
\Xi \\
\Xi\end{array}$ & 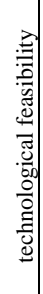 & 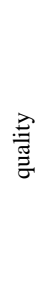 & $\begin{array}{l}0 \\
0 \\
0 \\
0 \\
: \\
0 \\
0 \\
0 \\
0\end{array}$ & 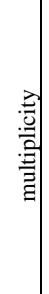 & $\begin{array}{l}3 \\
\vdots \\
\vdots \\
\vdots \\
\vdots \\
\vdots \\
0 \\
0 \\
0 \\
0 \\
0 \\
0 \\
0 \\
\vdots\end{array}$ & \\
\hline $\begin{array}{l}\text { Penev and De } \\
\text { Ron, } 1996\end{array}$ & & 1 & 1 & 1 & & & & & 1 & 1 & 1 & & & & & & & & & & \\
\hline $\begin{array}{l}\text { Krikke et al., } \\
1998\end{array}$ & & & & & & & & & & & & 1 & & & & & & & & & \\
\hline Lambert, 1999 & & & 1 & & & & & & & & & & & & & 1 & & & & & \\
\hline $\begin{array}{l}\text { Meimei et al., } \\
2002\end{array}$ & & & 1 & & & & & & & & & 1 & & 1 & & 1 & & & & & 1 \\
\hline $\begin{array}{l}\text { González and } \\
\text { Adenso-Díaz, } \\
2005\end{array}$ & & & 1 & & & & & & & & & & & & & & & & & & \\
\hline Teunter, 2006 & & & 1 & & & & & & & & & 1 & & & & & 1 & & & & \\
\hline $\begin{array}{l}\text { Xanthopoulos } \\
\text { and Iakovou, } \\
2009\end{array}$ & 1 & & & & & & & & & & & & & & & 1 & 1 & 1 & 1 & & 1 \\
\hline Lee et al., 2010 & & & 1 & & & & & & & & & 1 & & & & & & & & & \\
\hline Go et al., 2011 & & & 1 & & & & & & & & & & & 1 & & 1 & & & & & 1 \\
\hline $\begin{array}{l}\text { Kang and } \\
\text { Hong, } 2011\end{array}$ & & & 1 & & 1 & 1 & 1 & 1 & & & & & 1 & & 1 & 1 & & & & 1 & \\
\hline $\begin{array}{l}\text { Rickli and } \\
\text { Camelio, } 2012\end{array}$ & & & & & & & & & & & & 1 & 1 & & & & & & & & 1 \\
\hline $\begin{array}{l}\text { Vinodh et al., } \\
2012\end{array}$ & & & 1 & & & & & & & & & & & & & & & & & & \\
\hline Total & 1 & 1 & 9 & 1 & 1 & 1 & 1 & 1 & 1 & 1 & 1 & 5 & 2 & 2 & 1 & 5 & 2 & 1 & 1 & 1 & 4 \\
\hline
\end{tabular}

Table 9. Factors that make cleaning difficult in remanufacturing

\begin{tabular}{|l|l|}
\hline \multicolumn{1}{|c|}{ Factors } & \multicolumn{1}{c|}{ References } \\
\cline { 1 - 1 } complex structure: shape and geometric dimensions & Gamage, 2014, Li et al., 2015, Liu et al., 2013 \\
\hline material: hardness, composition, thermal stability & \\
\cline { 1 - 1 } excessive debris: density and thickness of the contaminant, on and inside the cores & Gamage, 2014, Li et al., 2015 \\
\cline { 1 - 1 } complexity of cleaning methods & Gamage, 2014, Liu et al., 2013 \\
\cline { 1 - 1 } environmental regulations & \multirow{2}{*}{ Gamage, 2014 } \\
\cline { 1 - 1 } corrosion & \\
\cline { 1 - 1 } form of output (whole units or part level) &
\end{tabular}


Table 10. Comparisons of some common cleaning techniques

\begin{tabular}{|c|c|c|c|c|c|c|}
\hline $\begin{array}{l}\text { Cleaning } \\
\text { technique }\end{array}$ & $\begin{array}{l}\text { High-temperature } \\
\text { decomposition }\end{array}$ & $\begin{array}{l}\text { Supercritical } \mathrm{CO} 2 \\
\text { cleaning }\end{array}$ & Liquid blasting & Shot blasting & Ultrasonic & Chemical solvents \\
\hline $\begin{array}{l}\text { Sources of } \\
\text { information }\end{array}$ & $\begin{array}{l}\text { Li et al., 2015, Liu et } \\
\text { al., 2013, Duan et al., } \\
\text { 2014, Peng et al., } \\
2016\end{array}$ & $\begin{array}{l}\text { Li et al., 2015, Liu et } \\
\text { al., 2015, Peng et al., } \\
2016\end{array}$ & $\begin{array}{l}\text { Long et al., 2014, } \\
\text { Liu et al., 2013, } \\
\text { Duan et al., 2014, } \\
\text { Peng et al., } 2016\end{array}$ & $\begin{array}{l}\text { Long et al., 2014, } \\
\text { Liu et al., 2013, } \\
\text { Duan et al., 2014, } \\
\text { Peng et al., } 2016\end{array}$ & $\begin{array}{l}\text { Liu et al., 2013, } \\
\text { Duan et al., } 2014\end{array}$ & $\begin{array}{l}\text { Li et al., 2015, Liu } \\
\text { et al., 2014, Liu et } \\
\text { al., 2013, Duan et } \\
\text { al., } 2014\end{array}$ \\
\hline $\begin{array}{l}\text { Suitable } \\
\text { surface }\end{array}$ & Iron casting & $\begin{array}{l}\text { Metal parts which } \\
\text { are heat-sensitive } \\
\text { and precision- } \\
\text { sensitive, aluminium }\end{array}$ & $\begin{array}{l}\text { Most types of } \\
\text { surface except } \\
\text { surface with } \\
\text { greasy dirt }\end{array}$ & $\begin{array}{l}\text { Casting surface; } \\
\text { descaling }\end{array}$ & $\begin{array}{l}\text { Delicate products, } \\
\text { most hard, non- } \\
\text { absorbent materials } \\
\text { (metals, plastics, } \\
\text { etc.), materialmade } \\
\text { from glass, plastic, } \\
\text { aluminium or } \\
\text { ceramic. }\end{array}$ & $\begin{array}{l}\text { Almost all types of } \\
\text { surface }\end{array}$ \\
\hline $\begin{array}{l}\text { Suitable type } \\
\text { of dirt }\end{array}$ & $\begin{array}{l}\text { Oil, grease and other } \\
\text { organic matter }\end{array}$ & $\begin{array}{l}\text { Oil, grease and other } \\
\text { organic matter }\end{array}$ & Rust, paint coats & Rust, paint coats & Oil and grease & $\begin{array}{l}\text { Scale deposit, } \\
\text { rust,oil and grease }\end{array}$ \\
\hline Cleaning agent & Air & Supercritical CO2 & Water & Abrasive materials & $\begin{array}{l}\text { Aqua based } \\
\text { solvents }\end{array}$ & Alkali or Acid \\
\hline Advantages & $\begin{array}{l}\text { 1. High ability to } \\
\text { clean greasy dirt }\end{array}$ & $\begin{array}{l}\text { 1. Few emissions } \\
\text { 2. Does not change } \\
\text { surface properties } \\
\text { 3. Mostly non- } \\
\text { flammable, } \\
\text { non-corrosive } \\
\text { 4.Low cleaning } \\
\text { temperature } \\
\text { 5. Faster technique } \\
\text { compared to high- } \\
\text { temperature } \\
\text { decomposition to } \\
\text { clean dirt }\end{array}$ & $\begin{array}{l}\text { 1. Simple } \\
\text { operation } \\
\text { 2. Low cost } \\
\text { 3. Does not } \\
\text { generate dust }\end{array}$ & $\begin{array}{l}\text { 1. Simple operation } \\
\text { 2. Low cost } \\
\text { 3. High applicability }\end{array}$ & $\begin{array}{l}\text { 1.Suitable for a } \\
\text { wide range of } \\
\text { workpiece shapes, } \\
\text { sizes and materials } \\
\text { 2. Not necessary to } \\
\text { disassemble } \\
\text { components before } \\
\text { cleaning. }\end{array}$ & $\begin{array}{l}\text { 1.Minimises the } \\
\text { material impact on } \\
\text { the core }\end{array}$ \\
\hline Disadvantages & $\begin{array}{l}\text { 1. Changes the } \\
\text { surface properties } \\
\text { 2.Cannot be used } \\
\text { with nonmetal and } \\
\text { heat-sensitive } \\
\text { components } \\
\text { 3. Needs high energy } \\
\text { and time } \\
\text { requirements, } \\
\text { 4. Combustion of } \\
\text { organic } \\
\text { contamination } \\
\text { generates } \mathrm{CO}_{2}\end{array}$ & $\begin{array}{l}\text { 1. Expensive } \\
\text { equipment } \\
\text { 2. Cannot handle } \\
\text { high polymer } \\
\text { 3. Requires another } \\
\text { cleaning method to } \\
\text { follow }\end{array}$ & $\begin{array}{l}\text { 1. Difficult to } \\
\text { clean the inner } \\
\text { cavity } \\
\text { 2. Consumes a lot } \\
\text { of water }\end{array}$ & $\begin{array}{l}\text { 1. Generates noise } \\
\text { and dust } \\
\text { 2. Difficult to clean } \\
\text { inner cavity } \\
\text { 3. May change } \\
\text { surface }\end{array}$ & $\begin{array}{l}\text { 1. Difficult to select } \\
\text { suitable cleaning } \\
\text { parameters for } \\
\text { different } \\
\text { contaminants } \\
\text { 2. Further surface } \\
\text { corrosion can occur } \\
\text { if cleaning } \\
\text { parameters are set } \\
\text { wrongly. } \\
\text { 3. Generates waste } \\
\text { which requires } \\
\text { further treatment }\end{array}$ & $\begin{array}{l}\text { 1.Harmful to } \\
\text { atmosphere } \\
\text { 2. Affects health } \\
\text { 3.Generates waste } \\
\text { which requires } \\
\text { further treatment } \\
\text { 4. May change the } \\
\text { surface of objects }\end{array}$ \\
\hline
\end{tabular}


Table 11. Review results about integrated decision making

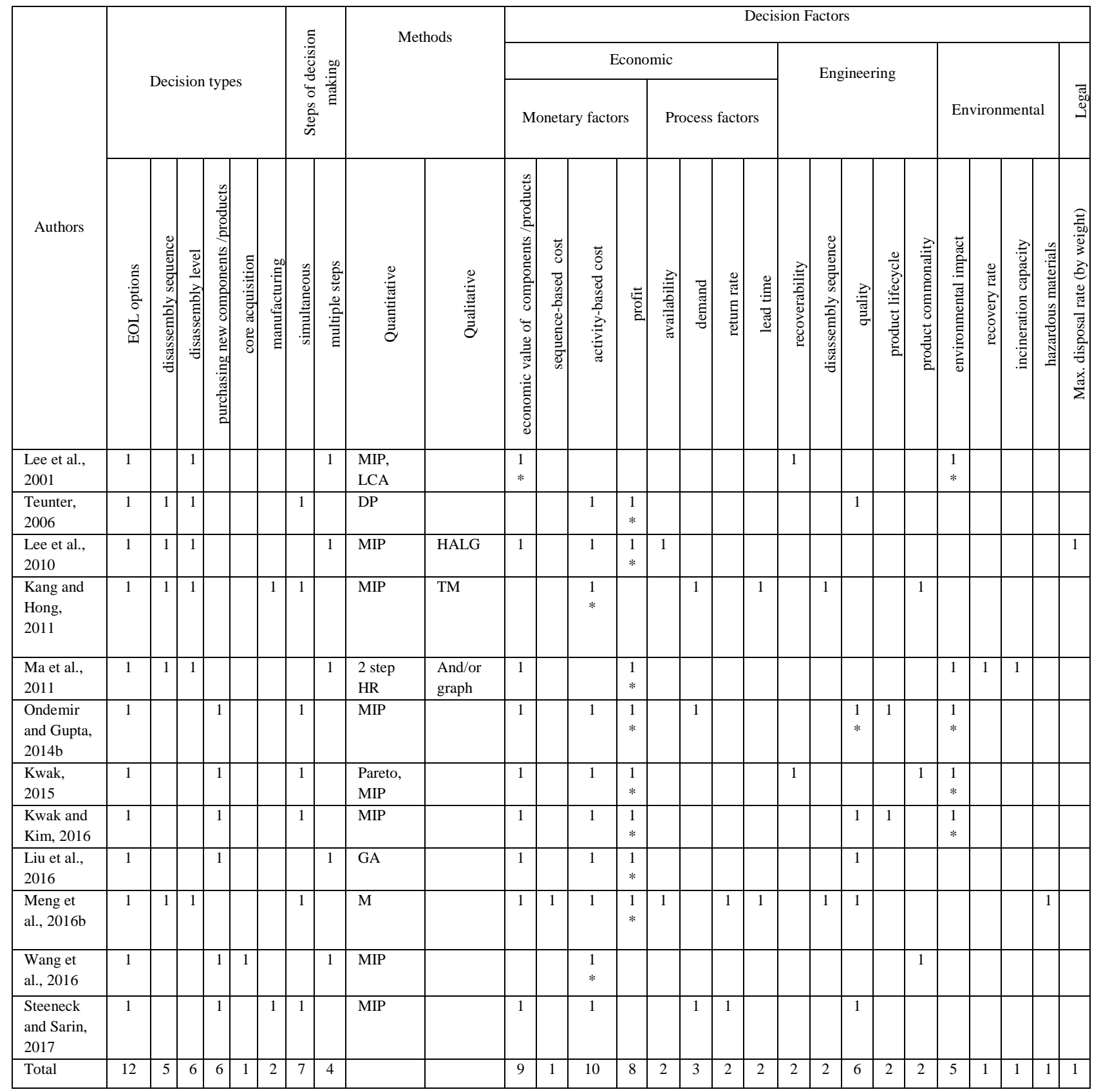

* = objectives, $\mathrm{MIP}=$ mixed integer programming, $\mathrm{LCA}=$ life cycle assessment, $\mathrm{DP}=$ dynamic programming, HALG = hierarchical attributed liaison graph, $\mathrm{TM}=$ transition matrix, $\mathrm{HR}=$ Heuristics, $\mathrm{GA}=$ Genetic algorithm, $\mathrm{M}=$ Metaheuristics 